\title{
Labour Market Institutions and Wage Inequality*
}

\author{
Winfried Koeniger ${ }^{a}$, Marco Leonardi $^{a}{ }^{b}$, Luca Nunziata $^{a}{ }^{b c}$
}

February 1, 2005

\begin{abstract}
In this paper we investigate the importance of labor market institutions such as unemployment insurance, unions, firing regulation and minimum wages for the evolution of male wage inequality across countries. We derive a simple log-linear equation of the wage differential as a function of the institutional parameters, total factor productivity, final good prices and relative skill supply. Our estimates for 11 OECD countries imply that labor market institutions can account for a large part of the change of wage inequality across countries after controlling for time and country effects.
\end{abstract}

Keywords: Labor market institutions, Wage differential by skill, Bilateral monopoly, Country panel data.

JEL Nos: E24, J31, J51, J65

\footnotetext{
${ }^{* a}$ IZA, Bonn; ${ }^{b}$ University of Milan; ${ }^{c}$ Nuffield College, Oxford. Koeniger: koeniger@iza.org; Leonardi: marco.leonardi@unimi.it; Nunziata: Luca.nunziata@nuffield.oxford.ac.uk. We thank Daron Acemoglu, our discussant Francine Blau and participants of the IZA workshop "Wage inequality, technology and institutions", the EALE 2004 and a seminar at the University of Milan for helpful comments. Financial support of DAAD-Vigoni is gratefully acknowledged. Corresponding author: Marco Leonardi, Dept. of Labor Studies, University of Milan, via Conservatorio 7, 20122 Milan, Italy.
} 


\section{Introduction}

Wage inequality is not only substantially lower in continental European countries than in the US or UK, but also its evolution over time is very different. A fairly consensual position is that the wage distribution reflects both supply and demand factors and the institutional environment. However, the quantitative importance of factor demand and supply compared with labor market institutions for wage inequality is still debated. A substantial amount of research on wage inequality has studied the forces that may shift the relative demand for skills such as changing trade patterns and skill biased technical change (see, for example, Machin and van Reenen, 1998, and their references). Since developed economies operate in the same global environment with integrated trade and equal access to technology, exogenous shifts in demand are likely to have been fairly similar across developed countries. Moreover, although countries expanded their education systems at different times, the proportion of the educated workforce has risen in all countries. Exogenous changes in supply and demand for skills are therefore unlikely to fully explain the different evolution of wage inequality across countries. Indeed, Acemoglu (2003) finds that the relative supply and demand framework does not provide an entirely satisfactory explanation of the behavior of skill premia across countries. Hence, there is scope for labor market institutions to be an important part of the story.

Of course, it is empirically very demanding to disentangle the effect of factor supply and demand from institutions. On the one hand, labor market institutions affect the relative market price for skills and therefore they change skill demand and supply. On the other hand, it is likely that institutions themselves respond to market forces (Acemoglu et al., 2001). In fact, the debate on the importance of skill supply and demand for wage inequality compared with institutions is still ongoing. Whereas Blau and Kahn $(1996,2004)$ stress that a substantial portion of cross-country wage differentials can be explained by labor market institutions, Nickell and Bell (1996), Nickell and Layard (1999) and Leuven et al. (2004) emphasize the importance of the net supply of skills. Unlike this literature, which investigates cross-country differences using cross sectional data, we focus on the different evolution of wage inequality within countries over time.

We use panel data on institutions in OECD countries to determine how much of the increase in wage inequality can be attributed to changes in institutions within countries. These data have become increasingly popular in the recent literature on the determinants of unemployment rates 
(see, for example, Blanchard and Wolfers, 2000, and especially Nickell et al., 2004) and average labor costs (Nunziata, 2002) across OECD countries. Under the "Krugman hypothesis", macroeconomic shocks increase wage inequality in countries where wages are flexible and unemployment where wages are constrained by institutions. Thus, the effect of such institutions on the wage differential can be considered as just the other side of the same coin (Bertola et al., 2002).

We build on this literature to assess the quantitative relationship between institutions and male wage inequality. Within a simple model of union wage determination we derive a log-linear equation of the wage differential as a function of institutions, total factor productivity, final good prices and relative skill supply. We estimate this equation for 11 OECD countries in the time period 197399 using OECD data on $\log 90-10, \log 90-50$ and $\log$ 50-10 wage differentials for male workers. Following closely the model predictions, we control for trade, technology and the relative supply of skills: the ratio of imports to value added shall measure the effect of trade on relative labor demand; the ratio of $R \& D$ to value added shall capture changes in technology and the relative endowment of educated population approximates relative skill supply. An adequate control for the relative skill supply is made difficult by the lack of long time series on the relative unemployment rate by skill. We control for the share of population with a college degree, the total unemployment rate and the interaction of the two. In some specifications we also include some controls for workforce composition such as the share of female workforce, the age composition of employment and the share of public expenditure on GDP.

We find that the employment protection index, the unemployment benefit generosity and duration, union density and the ratio of the minimum wage to the median wage are significantly associated with the evolution of wage inequality within countries. These results are robust to several different specifications. Furthermore we find that labor market institutions account for large part of the remaining variation in wage inequality after controlling for country and time effects. We illustrate the quantitative importance of institutions by calculating the implied change of the wage differential as institutions change. In particular, we compute the implied change of the wage differential if countries adopted an US-type institutional environment.

Of course, a serious concern is the endogeneity of unemployment in the wage-inequality equation. To check the robustness of our results without pretence to address endogeneity fully, we estimate a system of equations where unemployment is explicitly modelled following the literature on unemployment and institutions (Nickell et al. 2004). Identification is obtained through different 


\begin{tabular}{|c|c|c|c|c|}
\hline & & 1970s & $1980 \mathrm{~s}$ & $1990 \mathrm{~s}$ \\
\hline \multirow{3}{*}{ Wage differential: w90/w10 } & US & 3.488 & 4.049 & 4.627 \\
\hline & UK & 2.566 & 2.949 & 3.344 \\
\hline & France & 3.467 & 3.385 & 3.368 \\
\hline \multirow[t]{3}{*}{ Union density } & US & 0.250 & 0.191 & 0.152 \\
\hline & UK & 0.546 & 0.509 & 0.381 \\
\hline & France & 0.210 & 0.147 & 0.101 \\
\hline \multirow[t]{3}{*}{ Benefit replacement ratio } & US & 0.278 & 0.296 & 0.266 \\
\hline & UK & 0.341 & 0.263 & 0.226 \\
\hline & France & 0.562 & 0.607 & 0.585 \\
\hline \multirow[t]{3}{*}{ R\&D intensity } & US & 0.064 & 0.088 & 0.085 \\
\hline & UK & 0.109 & 0.105 & 0.086 \\
\hline & France & 0.048 & 0.055 & 0.073 \\
\hline \multirow[t]{3}{*}{ Import intensity } & US & 0.022 & 0.035 & 0.049 \\
\hline & UK & 0.064 & 0.086 & 0.103 \\
\hline & France & 0.049 & 0.070 & 0.091 \\
\hline \multirow[t]{3}{*}{ Skill ratio } & US & 0.379 & 0.546 & 0.867 \\
\hline & UK & 0.100 & 0.133 & 0.184 \\
\hline & France & 0.174 & 0.233 & 0.315 \\
\hline
\end{tabular}

Notes: For the definition and data sources of the variables see the data appendix which also contains the averages for the other countries in the sample.

Table 1: The evolution of some variables of interest for selected OECD countries

shocks affecting wage inequality and unemployment. In particular, money supply shocks are assumed to influence unemployment but not wage inequality. Our results on the effects of institutions on male wage inequality are robust to this modeling of unemployment as an endogenous variable.

The results of our aggregate cross-country panel estimation confirm the results on the importance of labor market institutions for the wage differential found in other country or institutionspecific empirical studies. Stronger and more centralized unions or minimum wages tend to compress the wage distribution. For example, Card (2001) for the US, Machin (1997) for Britain, Card et al. (2003) for the US, UK and Canada and Kahn (2000) for OECD countries, find that higher union density is associated with lower wage inequality. Di Nardo et al. (1996), Lee (1999) for the US, and Dickens et al. (1999) for the UK, find that higher minimum wages lower wage inequality. Moreover, wage-setting institutions are found to be important for wage inequality in Erickson and Ichino (1995) and Manacorda (2004) for Italy, Edin and Holmlund (1995) for Sweden. Only Wallerstein (1999) analyzes wage inequality and institutions for a set of 16 developed countries in the years 1980, 1986 and 1992. Our analysis extends the work of Wallerstein. Our sample consists of an 
unbalanced panel of 11 countries and 26 years so that our sample is more than four times larger in regressions controlling for country and time effects (175 instead of 40 observations). Moreover, we provide evidence for additional institutions such as employment protection regulation, the tax wedge, unemployment benefit generosity and duration. The theoretical part of this paper offers a simple explanation of the wage-compressing role of institutions based on their effect on the outside option of firms and workers.

In this paper we exploit time-series variation in several institutions while controlling for contemporaneous shifts in factor supply, trade volumes and technology. To further motivate the relevance of this perspective, Table 1 displays the evolution of some variables of interest. Wage inequality increased in the US and the UK but slightly declined in France. Trade intensity and R\&D intensity are rising in the three countries. Factor supply is also rising in the three countries although at different rates. Abraham and Houseman (1995) claim for example that supply of skilled labor grew faster in Germany than in the US and this pattern contributed to the more rapid growth in wage inequality in the US compared with Germany. In this paper we focus on the role of institutions, after controlling for changes in factor supply. It is clear in Table 1 that institutional variables such as union density and benefit replacement rates follow a country-specific pattern and look very promising in explaining different within-country changes in wage inequality.

The rest of the paper is structured as follows. Before we start our empirical exercise we set up a simple model in Section 2 and derive a log-linear equation of the wage differential as a function of the institutional parameters, total factor productivity, final good prices and relative skill supply. In Section 3 we present the data set and discuss the empirical specification. The estimation results are presented in Section 4 together with the results of some thought experiments. We summarize our findings and mention directions for further research in Section 5.

\section{$2 \quad$ A model}

We set up a simple model of union bargaining in which institutions affect the wage differential by altering labor demand and the surplus of producers and workers. We first derive the wage differential for the benchmark of perfect competition before we analyze the case of bilateral monopoly. 
Workers Agents are risk-neutral and have an infinite horizon. The economy is endowed with $\bar{h}$ skilled and $\bar{l}$ unskilled workers who inelastically supply labor. If employed, they earn wage $w_{h}$ and $w_{l}$, respectively. Should there be a minimum wage $\underline{w}$, we assume that $w_{h}>\underline{w}>w_{l}$. If workers are unemployed, they receive unemployment benefits $\rho_{k} w_{k}, k=h, l$, where $\rho_{k}$ is the replacement ratio. ${ }^{1}$ Employed workers are collectively dismissed by producers with Poisson probability $\lambda$. Given these assumptions and stationarity, for small time intervals the asset value of employment, $W_{k}$, and unemployment, $U_{k}$, are

$$
\begin{gathered}
r W_{k}=\max \left\{w_{k}, \underline{w}\right\}+\lambda\left(U_{k}-W_{k}\right), \\
r U_{k}=\rho_{k} \max \left\{w_{k}, \underline{w}\right\}+\lambda \theta_{k}\left(W_{k}-U_{k}\right),
\end{gathered}
$$

where $k=h, l$ and

$$
\theta_{h} \equiv \frac{h}{\bar{h}-h} \text { and } \theta_{l} \equiv \frac{l}{\bar{l}-l},
$$

$r$ is the market interest rate, and $h, l$ denote employment of skilled and unskilled workers in the economy. We have implicitly assumed that $U_{h} \geq W_{l}$ so that it is not optimal for skilled workers to perform unskilled tasks. Moreover, for workers to find it optimal to supply labor, the replacement ratio $\rho_{k}$ needs to such that $W_{k} \geq U_{k}, k=h, l$. This inequality is certainly satisfied as long as $\rho_{k}<1$ which is realistic.

In a stationary equilibrium the flows in and out of employment need to be equal: for example for unskilled workers $\lambda l=\lambda \frac{l}{\bar{l}-l}(\bar{l}-l)$. This can be interpreted as the number of available jobs being randomly allocated across unemployed workers. Subtracting equation (2) from equation (1), we find that the surplus from employment is

$$
W_{k}-U_{k}=\frac{\left(1-\rho_{k}\right) \max \left\{w_{k}, \underline{w}\right\}}{r+\lambda u_{k}^{-1}}
$$

where we define the unemployment rate $u_{k} \equiv(\bar{k}-k) / \bar{k}, k=h, l$, so that $\theta_{k}=u_{k}^{-1}-1$. In what follows we derive $w_{l}$ and the wage differential for the case that the minimum wage does not bind. As we will see, in our model a minimum wage compresses the wage differential from below in a

\footnotetext{
${ }^{1}$ We do not explicitly model the generosity of unemployment benefits as a function unemployment duration. Denoting the duration of unemployment as $\tau$, explicit modeling of duration dependent unemployment benefits would change equation (2) to $r U_{k}(\tau)=\rho_{k}(\tau)+\lambda \theta_{k}\left(W_{k}-U_{k}(\tau)\right)+U_{k}^{\prime}(\tau)$, where $U_{k}^{\prime}(\tau)<0$ if benefits fall over time. Duration dependent benefits would introduce wage differentials for otherwise identical workers in our model from which we abstract for simplicity. Qualitatively, the effect of duration-dependent benefits is similar to comparative statics with respect to the level of benefits in our model.
} 
straightforward way.

Production Two goods are produced in two sectors (denoted by the subscript $i$ ) with different technologies. Both sectors employ skilled and unskilled labor but with different factor intensities $\psi_{i}$. The technology in both sectors is assumed to be Cobb-Douglas with constant returns to scale:

$$
q_{i}\left(h_{i}, l_{i}\right)=a_{i} h_{i}^{\psi_{i}} l_{i}^{1-\psi_{i}}, i=1,2
$$

where $a_{i}$ is the total factor productivity in sector $i$ and we assume that $\psi_{1}<\psi_{2}$.

To set-up a production unit producers incur a sunk cost $C>0$ so that the asset value of production needs to be strictly positive to compensate for this sunk cost. Each production unit is closed down for exogenous reasons with Poisson probability $\lambda$ in case of which producers incur wasteful $^{2}$ dismissal costs $\delta_{k}=s_{k} w_{k}, k=h, l$, for each employed skilled and unskilled worker. ${ }^{3}$ Hence, collective dismissal costs for each production unit are $s_{h} w_{h} h_{i}+s_{l} w_{l} l_{i}$. ${ }^{4}$ This specification of dismissal costs allows simple analytic results since labor demand remains essentially static: dismissal costs affect wages like an ad-valorem firing tax.

The government taxes labor income of skilled and unskilled workers with ad-valorem rates $\tau_{h}$ and $\tau_{l}$ to finance the unemployment benefits. We assume that the government has to break even every period so that

$$
\tau_{h} w_{h} h+\tau_{l} w_{l} l=\rho_{h} w_{h}(\bar{h}-h)+\rho_{l} w_{l}(\bar{l}-l)
$$

The asset value of production in each sector is

$$
(r+\lambda) V_{i}=p_{i} q_{i}\left(h_{i}, l_{i}\right)-\left(1+\tau_{l}+\lambda s_{l}\right) w_{l} l_{i}-\left(1+\tau_{h}+\lambda s_{h}\right) w_{h} h_{i}
$$

where $p_{i}$ is the price of the good in sector $i$. We assume a small open economy so that prices are taken as given. Furthermore, free entry implies that $V_{i}=C$. Sunk costs generate quasi-rents after firms have entered the market and these rents can be appropriated by producers or workers.

\footnotetext{
${ }^{2}$ If wages are downward flexible and firing costs take the form of severance payments, Lazear (1990) has shown that the effect of firing costs is neutralized ex ante.

${ }^{3}$ We could also allow for differences in $\lambda$ across skills or industry. All that matters, however, are differences in $\lambda \delta$ which we are able to capture in the simple way proposed in the text.

${ }^{4}$ For this to make sense it needs to be the case that a single worker contributes an infinitely small amount to the production unit's labor force. Discreteness instead would imply the possibility that workers work for more than one production unit which would unnecessarily complicate the model.
} 
Once firms have sunk their investment and hired the workers, collective bargaining decreases the producers' outside option from $\underline{V}_{i}=0$ to $\underline{V}_{i}=-\left(s_{l} w_{l} l_{i}+s_{h} w_{h} h_{i}\right):^{5}$ collective dismissal costs create a hold-up problem that allows workers to collectively bid up their wage.

Note that all policy parameters enter the model proportional to wages. From a modeling perspective this allows us to derive a simple expression for the wage differential. However, the proportionality is also realistic to the extent that in many countries the policies we analyze have components which are indeed proportional to wage income. We now derive an explicit expression for the wage differential as a function of the policy parameters. We first start with the competitive benchmark and then compare it to case of collective bargaining.

Wage differentials under perfect competition Consider the benchmark of $C=0$ and perfect competition in the labor market. Then, equations (4) and (6) imply

$$
\begin{gathered}
\left(1+\tau_{h}+\lambda s_{h}\right) w_{h}=p_{i} a_{i} \psi_{i} \sigma_{i}^{\psi_{i}-1}, \\
\left(1+\tau_{l}+\lambda s_{l}\right) w_{l}=p_{i} a_{i}\left(1-\psi_{i}\right) \sigma_{i}^{\psi_{i}},
\end{gathered}
$$

where $\sigma_{i}$ denotes the skill ratio $h_{i} / l_{i}$. The gross labor cost for each worker (including expected dismissal cost) equals productivity and is the same in both sectors because of labor mobility. Replacement ratios are irrelevant since the labor supply is inelastic for $\rho_{k}<1$ as mentioned above. Instead, they will matter for the solution obtained under collective bargaining below because they affect the outside option of workers $U_{k}$.

The system of four equations (7) and (8) determines wages and skill ratios in both sectors. Defining $\widetilde{w}_{k} \equiv\left(1+\tau_{k}\right) w_{k}$ as gross wage, which is what we observe empirically, the following holds:

\section{Remark 1 (Perfect Competition): The log wage differential is}

$$
\ln \left(\frac{\widetilde{w}_{h}}{\widetilde{w}_{l}}\right) \simeq c+\lambda\left(s_{l}-s_{h}\right)+\left(\psi_{2}-\psi_{1}\right)^{-1}\left\{\ln \left(\frac{p_{2}}{p_{1}}\right)+\ln \left(\frac{a_{2}}{a_{1}}\right)\right\}
$$

\footnotetext{
${ }^{5}$ Of course, before a firm hires any worker, the outside option ex ante is $\underline{V}_{i}=0$ even under collective bargaining. Since the distinction between the ex ante and ex post bargain is not important for the empirical part of the paper (new firms that have just entered the labor market employ a negligible amount of workers in the aggregate), we focus on the empirically relevant case of ex post bargaining.
} 
where

$$
c\left(\psi_{1}, \psi_{2}\right) \equiv \frac{\psi_{2}}{\psi_{2}-\psi_{1}} \ln \left(\frac{\psi_{2}}{\psi_{1}}\right)+\frac{1-\psi_{1}}{\psi_{2}-\psi_{1}} \ln \left(\frac{1-\psi_{2}}{1-\psi_{1}}\right) .
$$

Proof: see the Appendix B.

Since sector 2 uses a more skill-intensive technology, $\psi_{2}>\psi_{1}$, the wage differential increases in the relative price and total factor productivity of the skill-intensive good. Gross wages and thus also the wage differential do not depend on ad-valorem taxes $\tau_{k}$ because the Cobb-Douglas production function is unit elastic: the downward shift of labor demand implies a fall in net wages $w_{k}$ which is exactly offset by the direct positive effect $\tau_{k}$ on gross wages $\widetilde{w}_{k}$. Producers are able to fully pass on the cost to workers who supply labor inelastically. Expected collective dismissal costs per worker, $\lambda s_{k}$, decrease gross wages as the expected firing tax is passed on to workers (this would not be the case if our definition of gross wages also included the expected firing tax which is however not the case empirically). The effect on the wage differential depends on whether such costs are larger for unskilled or skilled workers.

Under perfect competition individual employed workers can be replaced without cost so that they cannot bid up their wages ex post. Instead, as we will see now, this is no longer the case if unions bargain for all workers.

Wage differentials with union bargaining Producers and a workers' union bargain over how to split the rents of the two sectors ${ }^{6}$ where rents are positive because of sunk costs $C>0$. We adopt the right-to-manage framework in which unions ${ }^{7}$ and (an employer association of) producers bargain over the wage. Producers then unilaterally choose employment so that labor is on the labor demand curve. Although the right-to-manage setup has been criticized since producers and unions could do better if they bargained efficiently over both wages and employment, right-to-manage for producers is considered more realistic by most economists. For example, Farber (1986) discusses

\footnotetext{
${ }^{6}$ Both sectors might belong to one industry. Industry level bargaining is a good approximation for countries like Germany, the Netherlands, Belgium and also to some extent the UK, France and Italy (see, e.g., Calmfors and Driffill, 1988). However, many countries have moved to more decentralized bargaining according to Freeman and Gibbons (1995). Nothing prevents us from interpreting $i$ as the suitable unit of disaggregation such as firm, profession, sector or industry.

${ }^{7}$ Decentralized bargaining of a single worker with producers would substantially complicate the solution of the model. As discussed in Stole and Zwiebel (1996a and 1996b), firms have a strategic incentive to overemploy workers if the technology has decreasing returns to scale. However, as noted in Stole and Zwiebel (1996b), unions internalize the effect of a single worker's bargain on other workers' bargaining position. With unionization no incentive for overemployment arises, as in our model where unions bargain for both skilled and unskilled workers and the production function has constant returns to scale for both factors together.
} 
enforceability problems of contracts if firms are off their labor demand curve.

With right-to-manage the Nash bargaining problem is

$$
\begin{gathered}
\max _{w_{k}} \Omega^{\beta} \sum_{i=1}^{2}\left(V_{i}-\underline{V}_{i}\right) \\
\text { s.t. } l_{i}=l_{i}^{D}\left(w_{h}, w_{l}\right) \text { and } h_{i}=h_{i}^{D}\left(w_{h}, w_{l}\right),
\end{gathered}
$$

where $\beta$ is the relative bargaining power of the union, superscript $D$ denotes the demand curve and the union objective is defined as

$$
\Omega \equiv \xi\left(W_{h}-U_{h}\right)+\left(W_{l}-U_{l}\right)
$$

The union only cares about employed workers and $\xi$ denotes the relative weight of unskilled employed workers: the larger $\xi$, the more aggressively the union will bargain for unskilled workers. We extend the model to union concerns about unemployment when we discuss the effects of union coordination or centralization below. Note that unions do not cross-subsidize between workers as in Acemoglu et al. (2001) but both skilled and unskilled workers earn their marginal product. However, interactions between both factors arise as long as the production technology implies some complementarity between factors. Moreover, the small-open economy assumption excludes feedbacks from union's wage setting on prices (such externalities are considered for example by Calmfors and Driffill, 1988). Finally, we only consider interior optima in which the supply of skilled and unskilled labor is not constrained by the endowment $\bar{h}, \bar{l}$. In the empirical part we will control for the relative skill supply to address this issue.

The explicit expression for the producers' surplus is

$\sum_{i=1}^{2}\left(V_{i}-\underline{V}_{i}\right)=(r+\lambda)^{-1}\left\{q_{1}(\cdot)+\frac{p_{2}}{p_{1}} q_{2}(\cdot)-\left(1+\tau_{h}-r s_{h}\right) w_{h}\left(h_{1}+h_{2}\right)-\left(1+\tau_{l}-r s_{l}\right) w_{l}\left(l_{1}+l_{2}\right)\right\}$.

We now proceed to derive the solution of the bargain. The first-order condition of problem (9) for skilled wages is

$$
\beta \Omega^{\beta-1} \sum_{i=1}^{2}\left(V_{i}-\underline{V}_{i}\right) \frac{\partial \Omega}{\partial w_{h}}-\Omega^{\beta} \frac{1+\tau_{h}-r s_{h}}{r+\lambda} \sum_{i=1}^{2}\left(h_{i}+\frac{\partial h_{i}}{\partial w_{h}} w_{h}\right)=0
$$


Multiplying by $w_{h}$ and $h / h$ and rearranging, we get

$$
w_{h} h=\frac{(r+\lambda) \beta \sum_{i=1}^{2}\left(V_{i}-\underline{V}_{i}\right) \varepsilon_{h}}{\left(1+\tau_{h}-r s_{h}\right)\left(1+\sum_{i=1}^{2} \frac{h_{i}}{h} \eta_{h, i}\right)},
$$

where $\varepsilon_{h} \equiv\left(\partial \Omega / \partial w_{h}\right) /\left(w_{h} / \Omega\right)$ and $\eta_{h, i} \equiv\left(\partial h_{i} / \partial w_{h}\right) /\left(w_{h} / h_{i}\right)$ denote the elasticity of the union objective and labor demand with respect to $w_{h}$.

Analogous derivation of $w_{l} l$ allows to write the relative labor share of the two factors net of taxes as

$$
\frac{w_{h} h}{w_{l} l}=\frac{1+\tau_{l}-r s_{l}}{1+\tau_{h}-r s_{h}} \frac{1+\sum_{i=1}^{2} \frac{l_{i}}{l} \eta_{l, i}}{1+\sum_{i=1}^{2} \frac{h_{i}}{h} \eta_{h, i}} \frac{\varepsilon_{h}}{\varepsilon_{l}} .
$$

Intuitively, the relative labor share of skilled labor depends negatively on the relative taxes and relative labor demand elasticities but positively on the relative elasticity of the union objective with respect to wages.

We now use the expression for the relative labor share to derive the wage differential as a function of the model's policy parameters. It remains to derive explicit expressions for the skill ratio $h / l$ and the elasticities. The Cobb-Douglas production function implies that the second term on the right-hand side of (11) equals 1 (to see this apply L'Hôpital's rule for the more general case with a CES function and consider the limit to the Cobb-Douglas case). Furthermore, in this case relative labor demand can be derived using (4) and (6):

$$
h / l=\frac{a_{1} \psi_{1} q_{1}+a_{2} \psi_{2} \frac{p_{1}}{p_{2}} q_{2}}{a_{1}\left(1-\psi_{1}\right) q_{1}+a_{2}\left(1-\psi_{2}\right) \frac{p_{1}}{p_{2}} q_{2}} \frac{1+\tau_{l}+\lambda s_{l}}{1+\tau_{h}+\lambda s_{h}} \frac{w_{l}}{w_{h}}
$$

The Cobb-Douglas technology implies that the total labor share is constant unless prices or productivity change. Hence, for given prices and productivity it follows from (11) that $\varepsilon_{h} / \varepsilon_{l}$ is pinned down, too. In the Appendix we derive that

$$
\frac{\varepsilon_{h}}{\varepsilon_{l}}=\xi \frac{1-\rho_{h}}{1-\rho_{l}} \frac{r+\lambda u_{l}^{-1}}{r+\lambda u_{h}^{-1}} \frac{w_{h}}{w_{l}} .
$$

Quite intuitively, the elasticities depend on the marginal effect of wages on the employed workers' surplus applying the weight $\xi$ in the union objective: the marginal effect is $\xi\left(1-\rho_{h}\right) /\left(r+\lambda u_{h}^{-1}\right)$ for skilled workers and $\left(1-\rho_{l}\right) /\left(r+\lambda u_{l}^{-1}\right)$ for unskilled workers.

Plugging (13) and (12) into (11) and rearranging, we get 
Remark 2 (Union Bargaining): If unions and producers bargain over wages and producers retain the right to employ workers, the log wage differential is given by

$\ln \left(\frac{\widetilde{w}_{h}}{\widetilde{w}_{l}}\right) \simeq-\ln (\xi)+\left(\tau_{h}-\tau_{l}\right)+(r+\lambda)\left(s_{h}-s_{l}\right)+\left(\rho_{h}-\rho_{l}\right)+\ln v\left(u_{-}, u_{l}\right)+\ln \pi\left(a_{2} / a_{1}, p_{2} / p_{1}\right)$

with

$$
v\left(u_{h}, u_{l}\right) \equiv \frac{r+\lambda\left(1+u_{h}^{-1}\right)}{r+\lambda\left(1+u_{l}^{-1}\right)} \quad \text { and } \quad \pi\left(a_{2} / a_{1}, p_{2} / p_{1}\right) \equiv \frac{\psi_{1}+\frac{a_{2}}{a_{1}} \frac{p_{2}}{p_{1}} \frac{q_{2}}{q_{1}} \psi_{2}}{\left(1-\psi_{1}\right)+\frac{a_{2}}{a_{1}} \frac{p_{2}}{p_{1}} \frac{q_{2}}{q_{1}}\left(1-\psi_{2}\right)}
$$

and $\psi_{1}<\psi_{2}$.

Proof: see the Appendix B.

Compared to the benchmark of perfect competition in Remark 1, relative gross wages now also depend on relative unemployment rates and replacement ratios. Although union bargaining power $\beta$ cancels and does not directly affect the wage differential, it is worth noting that in the limit $\beta \rightarrow 0$ we are back in the case of perfect competition. For $\beta>0$ instead, union bargaining implies that wages do no longer adjust to clear labor markets and some workers remain unemployed. Low unemployment rates increase the (re)employment probability and similar to high replacement ratios $\rho_{k}$ strengthen the outside option of workers $U_{k}$ (see equation (2)). A better outside option implies a better bargaining position and higher wages. Thus, the wage differential depends on the relative strength of the outside option. For example, a higher replacement ratio or reemployment probability for unskilled workers lowers the wage differential. Of course, the relative unemployment rate is jointly determined, an issue that we will address in the empirical part. Trivially, the wage differential is also smaller if unions favor unskilled workers more $(\xi>1)$.

As in the perfectly competitive benchmark, higher relative total factor productivity or prices in the skill-intensive sector 2 induce higher relative labor demand for skilled workers (see equation (12)) so that the wage differential increases.

Collective dismissal costs compress the wage differential if they are relatively more important for unskilled workers. As mentioned above, dismissal costs create a hold-up problem. Unions thus bargain more aggressively taking into account the negative effect of wages on the producers' outside option. Note that this effect crucially depends on dismissal costs being proportional to wages.

Ad-valorem taxes matter for the gross wage differential but are irrelevant for net wages. This 
is because unions can appropriate less rents if taxes are higher. For Cobb-Douglas technology this effect exactly cancels with the adverse effect on labor demand (see equations (11) and (12)).

Finally, let us mention that labor market institutions that directly affect the wage differential such as minimum wages, $\underline{w}$, compress the wage differential: by definition, for a binding minimum wage, $\underline{w} \geq w_{l}$, whereas $w_{h}$ is not directly affected.

Before estimating an equation such as (14), we want to relax the assumption that the union does not take into account the effect of its wage setting on unemployment. We now analyze whether union coordination or centralized bargaining which internalizes this externality, compresses the wage differential.

Centralized bargaining or union coordination Unions take the externalities of their wage setting on unemployment into account. ${ }^{8}$ The objective function of the union (10) remains the same but in equation (3) unions now consider $u_{k}, k=h, l$, as an endogenous determinant of the employment surplus $W_{k}-U_{k}$. Compared with above

$$
\frac{\partial\left(W_{k}-U_{k}\right)}{\partial w_{k}}=\frac{\left(1-\rho_{k}\right)}{r+\lambda u_{k}^{-1}}+\frac{\left(1-\rho_{k}\right) \lambda u_{k}^{-1}}{\left(r+\lambda u_{k}^{-1}\right)^{2}} \zeta_{k} \eta_{k}, k=h, l,
$$

where $\zeta_{k} \equiv\left(\partial u_{k} / \partial k\right) /\left(k / u_{k}\right)$ and $\eta_{k} \equiv\left(\partial k / \partial w_{k}\right) /\left(w_{k} / k\right)$. The additional second term is positive: the outside option deteriorates so that the employment surplus $W_{k}-U_{k}$ increases relatively more than in the previous section. This implies that the union is less aggressive in the wage bargain.

Remark 3 (Union Coordination): Coordination or centralization of union bargaining compresses the wage differential if $u_{h}<u_{l}$.

Proof: see the Appendix B.

As shown in the Appendix, union coordination adds a log-linear term to (14). The term is negative if $\zeta_{l} \eta_{l} /\left(\zeta_{h} \eta_{h}\right)$ is not too large. Intuitively, union coordination moderates union behavior in wage bargaining more if labor demand and unemployment are more elastic. Thus, the effect of coordination on the wage differential depends on the relative size of these elasticities. For Cobb-

\footnotetext{
${ }^{8}$ This is a shortcut similar to Layard et al. (1991) and Blanchard and Summers (1986). Modelling centralization of bargaining explicitly such as for example in Calmfors and Driffill (1988) or Danthine and Hunt (1994) prevents us from deriving an analytically tractable expression for the wage differential.
} 
Douglas technology, $\eta_{l} / \eta_{h}=1$. Using the explicit expression for $u_{k}$ in our model, we show in the Appendix that the condition simplifies to $u_{h}<u_{l}$ since $\zeta_{k}$ decreases in $u_{k}$ in our model.

We have shown how the wage differential depends on various institutional parameters in a simple log-linear way. Of course, we only have been able to derive such an equation because we have modelled institutions in an extremely stylized way. In reality, institutions are much more complex and might affect wage differentials in various other ways. For example, union coordination or centralization might compress wage differentials if the union agreement has wider applicability in the economy and allows unions to better insure its members (Wallerstein, 1990); or if centralized unions mitigate the hold-up problem in the context of aggregate shocks (Teulings and Hartog, 1998). Moreover, in our model labor supply is inelastic and wage differentials depend on differences of the workers' outside option. A complementary view is that labor supply is elastic and the elasticity differs across demographic groups (Bertola et al., 2003). In this case more powerful unions that compress wages, price young, old and female workers out of the labor market because these groups of the population are less strongly attached to the labor force. Note also that employment protection affects labor shares and wages over the business cycle as it renders labor demand dynamic (see Bertola, 1999, on the countercyclical behavior of labor shares in dynamic labor demand models). Furthermore, unions might try to change the bargain by lobbying for certain institutions. For example, countries with strict regulation on employment protection also tend to have institutions that compress wages from below such as minimum wages (Bertola and Rogerson, 1997). Hence, one should be careful in interpreting the empirical estimates too literally in terms of the model, although we hope to have captured some important aspects of the labor market institutions for which we have data.

\section{Data and econometric model}

We now discuss the data that we use in our empirical analysis before we specify the econometric model (see Appendix A for further information on the data sources). From the derived log-linear equation above it follows that ideally we would like to have data on wage differentials, institutions and unemployment rates by skill, relative total factor productivity and prices of skilled and unskilled-labor intensive sectors.

In practice, the data on institutions contain measures of wage bargaining institutions, generos- 
ity and duration of unemployment benefits, strictness of employment protection legislation, labor taxation and minimum wages. Wage differentials by skill are not available for a long enough time period for a large enough number of countries. Thus, we use the ratio of the 90th to the 10th wage percentile, $w_{90} / w_{10}$, for male workers. We focus on males because the series are longer and the male wage is less affected by labor force participation changes over time. Although the measure $w_{90} / w_{10}$ is highly correlated with the wage differential by skill, we acknowledge that it might capture some within-group wage inequality about which the model is silent. Moreover, $w_{90} / w_{10}$ is an aggregate measure and thus captures the effect of union bargaining in the unionized sector as well as spill-overs to the non-union sector. However, the estimation results below suggest that such spill-overs do not dominate the effect in the unionized sector emphasized by our model.

In equation (14) trade and technology determine the wage differential through relative prices, $p_{2} / p_{1}$, and relative total factor productivity (TFP), $a_{2} / a_{1}$. As frequently done in the literature, we proxy the effect of trade by the ratio of imports over value added, imp intensity, and technology by the ratio of $\mathrm{R} \& \mathrm{D}$ expenditure over value added, $R D$ intensity, in the manufacturing sector (see Machin and van Reenen, 1998). Of course, in contestable markets imports might not change if foreign competition does, but in practice openness (and thus the exposure to competition) and trade volumes are highly correlated.

The relative unemployment rate of skilled workers matters for the wage differential in equation (14) because it affects the outside option of skilled and unskilled workers. Unfortunately data on unemployment by skill are not available for all countries and time periods on a comparable basis. As a measure of the relative unemployment rate, we use the relative skill endowment in the population $\log ($ skill $)$, the aggregate unemployment rate $\log (u)$ and the interaction of the two.

The time-varying data on institutions are crucial for our estimations. We now describe the data in some detail and further information is contained in the Appendix A. We have two measures on wage bargaining institutions: the union membership rate among active workers or union density, $U D$; and the index of coordination, $C O$. The union density is supposed to capture how aggressively the union bargains for higher wages of unskilled workers (the parameter $\xi$ in terms of the model). A higher union density will decrease the wage differential if it implies relatively more aggressive wage bargaining for unskilled workers. An alternative measure of union bargaining power is union coverage, i.e. the proportion of contracts covered by collective agreements. This variable has the advantage of giving more weight to unions in countries where the density is quite low but the 
bargaining power is high, as for example in the case of France. However, consistent series on union coverage for all countries are not available, apart for a few observations every 10 years (see Nickell et al., 2004). Fortunately, union coverage is very constant over time whereas this is not the case for union density. Differences in union coverage are thus controlled for by country fixed effects (the same holds for all other unobservable characteristics of countries that are constant over time). We are able to control for another heterogeneity of unions using an index of coordination in wage bargaining. This measure captures the extent to which parties internalize the macroeconomic consequences of their decisions and will moderate wage demands. The effect on the wage differential depends on the relative concerns about unemployment of skilled and unskilled workers (see Remark 3 above).

Concerning unemployment benefits we have data on benefit replacement rates, $B R R$, and benefit duration, $B D$. Benefit replacement rates measure the proportion of unemployment benefits relative to average earnings before tax, averaged over family types of recipients. Benefit duration measures the duration of the entitlement to unemployment benefits in each country and is defined as $B D=$ $\alpha\left(B R R_{2} / B R R_{1}\right)+(1-\alpha)\left(B R R_{4} / B R R_{2}\right)$, where the subscript 1 denotes the first year, 2 the second and third year and 4 the fourth and fifth year in unemployment. The model implies that both indicators should be negatively correlated with the wage differential if generous unemployment benefits increase the outside option of unskilled workers relatively more.

The data on employment protection legislation, EP, summarize the set of rules and procedures governing the treatment of dismissals of workers employed on a permanent basis. The tax wedge, $T W$, is defined as the sum of the employment tax rate, the direct tax rate and the indirect tax rate. Both indicators should be negatively correlated with the wage differential if implicit firing taxes and labor taxes are more important for unskilled workers. Finally, the measure of minimum wages is defined as the ratio between the minimum and median wage. Higher minimum wages compress the wage differential from below. Clearly, in some countries unemployment benefits or other welfare payments also implicitly truncate the wage distribution from below. In the econometric estimations the coefficients are identified from different time variation across countries. Thus, the levels of the institutional variables are less of a concern.

Table 2 (displayed at the end of the paper) contains summary statistics of the variables used in the estimation. The unbalanced panel of countries for the period 1973-99 includes Australia, Canada, Finland, France, Germany, Italy, Japan, the Netherlands, Sweden, the UK and the US. 
For more detailed information on the data see also the descriptive statistics in Tables 10 and 11. We now turn to the econometric specification of the estimated equation.

In Section 2 we have shown that labor market institutions matter for wage differentials, especially if labor markets are not perfectly competitive. We now proceed to empirically investigate whether and to what extent labor market institutions are related to the male wage differential in OECD countries. The empirical counterpart of equation (14) is the following:

$$
\log \left(\frac{w_{90}}{w_{10}}\right)_{i t}=\theta_{0}+\theta_{1} v_{i t}+\gamma^{\prime} \mathbf{z}_{i t}+\boldsymbol{\vartheta}^{\prime} \mathbf{s}_{i t}+d_{i}+d_{t}+\varepsilon_{i t}
$$

where $\frac{w_{90}}{w_{10}}$ is the male wage differential between the 90 th and 10 th percentile of the gross wage distribution, $\mathbf{z}_{i t}$ is a vector of labor market institutions indicators, $v_{i t}$ is a measure of the relative unemployment rate of the skilled, $\mathbf{s}_{i t}$ is a vector of controls for trade and technology shocks, $d_{i}$ is a fixed country effect, $d_{t}$ is a year dummy and $\varepsilon_{i t}$ is the stochastic error term.

In our regressions the institutions included in $\mathbf{z}_{i t}$ are employment protection $(E P)$, the benefit replacement ratio $(B R R)$, a measure of benefit duration $(B D)$, union density $(U D)$, coordination in wage bargaining $(C O)$, the tax wedge $(T W)$ and the minimum wage $(M W)$.

In order to get efficient estimates we adopt a feasible fixed effect GLS estimator, with a variancecovariance matrix that incorporates heteroskedasticity across countries (see Nunziata, 2002, for further discussion of the methodology). ${ }^{9}$

\section{Estimation results}

We present the estimation results in Tables 3-5 that are all displayed at the end of the paper. Our estimations show that institutions are strongly associated with wage inequality using both specifications in levels and in first differences. Tables 3-4 display results for the specification in levels whereas Table 5 contains results for the specification in first differences. The regressions in first differences are insightful because our technology measure, R\&D intensity, is a better indicator of the change in technology rather than the stock. Table 3 presents the baseline model which is augmented for interactions between institutions in Table 4. This decreases our sample size since such

\footnotetext{
${ }^{9}$ In an alternative specification we allow for serial correlation of the errors within countries. We find some evidence for an first-order autoregressive error structure with a common $\rho$ below 0.4. Since the estimated coefficients turned out to be almost identical, throughout the paper we present the estimations results which do not correct for serial autocorrelation of the errors within countries given that our sample is limited in the time series dimension.
} 
data are only available from the 80s onwards. However, this measure relates better to the literature on the effects of trade between developed and developing countries on the wage differential. Finally, in Tables 7 to 9 we present simulations that illustrate quantitatively how changes in institutions are related to wage differentials.

Table 3 displays the results for various regressions. Employment protection, the benefit replacement rate and duration, union density and the minimum wage are found significant across alternative specifications. The negative sign of the coefficients suggests that these policies are more important for unskilled than skilled workers. Columns (1)-(3) contain estimation results for the 90-10 male wage differential whereas columns (4) and (5) report the results of the preferred specification for the 90-50 and 50-10 male wage differential, respectively. The standard errors used for the z-statistics reported in brackets below the coefficient estimates allow for heteroskedasticity across countries. At the bottom of the Table we report two measures of fit: the root mean-squared error (RMSE) of the model allowing for heteroskedasticity and the R2-statistic of the corresponding OLS fixed-effect model. Both statistics reveal a high fit of the model specification.

Columns (1)-(3) contain results for the 90-10 male wage differential. Our preferred specification in column (1) includes time and country dummies as well as measures of trade, technology, the relative unemployment ratio and the institutional indicators. In column (1) the regressors on institutions and trade are highly significant. In particular, the 90-10 male wage differential is more compressed if employment protection legislation is stricter, or unemployment benefits, union density or minimum wages are higher. The index of coordination is also negatively associated with the wage differential but not significant. Also the tax wedge has no significant effect. Moreover, the male wage differential is positively associated with import intensity ${ }^{10}$ but negatively with R\&D intensity. This suggests that R\&D expenditure is not a good proxy for the stock of technology, being both an input and a flow variable. The effect of the stock of technology on the wage differential is likely to be captured at least partly by the country and time dummies in our regression. R\&D instead should be much more relevant in explaining changes in the wage differential rather than the level. As we will see below this is indeed the case in the regression on changes of the wage differential. Finally, our measures of the relative skill supply indicate that a higher endowment of

\footnotetext{
${ }^{10} \mathrm{We}$ also have run the regressions using the import-intensity of trade with non-OECD countries. The disadvantage of using this variable is that this import intensity is only available from the 80 s onwards so that the sample size decreases. Results which are not reported show that coefficient of the non-OECD import intensity is larger than the coefficient for the total import intensity. This supports the view that trade with less developed countries is more strongly associated with the wage distribution.
} 
skills is associated with higher wage inequality, while the effect of the unemployment rate is not significant.

In column (2) we augment the model with controls for workforce composition effects. These are the share of female labor force participation, the ratio of government expenditure over GDP and the age composition of employment measured by the share of workers above the age of 24 . The share of female workforce is relevant for male wage inequality inasmuch women are substitutes for low-skilled men as claimed by Topel (1994). The ratio of public expenditure compresses wage dispersion as long as public expenditure is a proxy for the share of public employment and wages within public employees are more compressed (Wallerstein, 1999). The age composition of employment controls for experience-wage profiles at the aggregate level.

The presence of workforce controls in column (2) does not affect the results on institutions except for the coefficients on coordination and the tax wedge which now become significant: a decrease in taxes and an increase in coordination are correlated with an increase in wage inequality. The coefficients of the workforce controls are all significant. The ratio of government expenditure enters with the expected negative sign. The coefficient on the share of workers over the age of 24 is positive suggesting that a higher proportion of workers at the top of their experience-wage profile is reflected in higher aggregate wage inequality. Finally, the share of women in the labor force is negatively associated with male wage inequality. This is in contrast with the findings of Topel (1994) for the US who found a positive relationship between women participation and male wage inequality. Controlling for age and skill groups, he claimed that the big increase in participation of skilled women increased male wage inequality because women are substitutes to low-skilled workers. Our results suggest that this substitution effect may not be robust for other countries.

Controlling for the workforce composition we have slightly less observations (160 instead of 175) due to the lack of data on age composition of employment for the UK at the beginning of the sample period. In the following we prefer to present the results without the controls for workforce composition which might be considered endogenous. However we always checked that our results are robust to the inclusion of these controls.

Comparing the results of column (1) with the results of column (3) which only includes time and country dummies, we observe that the additional regressors in the model substantially increase the fit. ${ }^{11}$ The RMSE changes from 0.084 to 0.038 and the R2 from 0.935 to 0.970 . Adding measures of

\footnotetext{
${ }^{11}$ Moreover, results that are not reported show that our explanatory variables alone explain more of the variation
} 
trade, technology and relative unemployment to the regression in column (4) changes the RMSE to 0.077 and the $\mathrm{R} 2$ to 0.950 (results not reported in the Table). These numbers imply that institutions can explain a large part of the remaining variation in column (4).

The results for the 90-50 and 50-10 male wage differentials reported in the Table help us to disaggregate the effect of institutions on the entire wage distribution. It turns out that the coefficients of employment protection, replacement rates and minimum wages are quantitatively similar for the upper and lower part of the wage distribution while union density is relatively more important for the upper part of the distribution (90-50). This finding is puzzling for the minimum wage and might be driven by imperfections of the measure discussed in the previous section. However, the coefficients of the minimum wage and of union density are more intuitive in the regressions below using differences of the wage differential. In addition, the unemployment rate is significantly positively associated with the wage differential in the lower part of the distribution and negatively associated with the wage differential in the upper part of the distribution.

The models in Table 4 include a set of interactions between labor market institutions. They account both for some complementarity in institutions and possible heterogeneity in the institutional coefficients. ${ }^{12}$ For example, labor taxes increase real wages more if unions are strong and decentralized where the interaction between these institution is likely to be non-linear (see Daveri and Tabellini, 2000, and Alesina and Perotti, 1997). Moreover, employment protection has relatively more bite if wages are rigid downward because of minimum wages (see Lazear, 1990, or Bertola and Rogerson, 1997). Finally, the generosity of unemployment benefits matters more the longer such benefits are provided (see, for example, Nickell et al., 2004). We expect the latter two policy interactions to compress the wage differential since they are likely to affect unskilled workers more strongly. The effect of the interaction between union density and coordination instead is less clear since it is predicted to be non-linear.

The variables on institutions enter in each interaction as deviations from the world average. In this way the coefficient of each institution in levels can be read as the coefficient of the "average" country, i.e. the country characterized by the average level of that specific institutional indicator. For this average country, the interaction terms are zero. We experimented with various interactions but only the interactions between union bargaining variables $(U D C O)$, employment protection and

\footnotetext{
than just country and year dummies.

${ }^{12}$ These specifications are in the spirit of Belot and van Ours (2001) who analyze the effect of institution interactions on unemployment.
} 
minimum wages $(E P M W)$ and benefit variables $(B R R B D)$ turned out to be significant.

Our results are robust to the introduction of the interactions. All three interactions are significant when introduced one at a time as can be seen in Table 4, columns (1)-(3). The interactions $E P M W$ and BRRBD have a negative sign which suggests that the interactions are more important for unskilled workers. In column (4) we include all three interactions at the same time and only the interaction between bargaining variables $(U D C O)$ and benefit variables $(B R R B D)$ remain significant. This is also true for the models using the 90-50 and the 50-10 wage differential in columns (5) and (6).

We check robustness of the results further dropping one country at a time. We find that only in one case do coefficients change substantially: the exclusion of Finland reduces the importance of union density. As the descriptive statistics in Table 11 show, one difference between Finland and most other countries in the sample is that union density has increased in Finland since the 1970s. Our results are also robust to the exclusion of the variables $R D$ intensity or imp intensity. Moreover, our results are qualitatively robust to the exclusion of the minimum wage variable that is identified by only six countries in which it changes over time. The sign and significance of the coefficients on $E P, B R R, B D$ and $U D$ are not affected by the removal of the minimum wage from the regression.

\subsection{First Differences}

We now move on to discuss the effect of trade, technology and institutions in a regression using changes of the wage differential as dependent variable. This is particularly interesting because our technology measure, $\mathrm{R} \& \mathrm{D}$ intensity, is a flow and not a stock and thus should be a better predictor of the change than the level of the wage differential.

Table 5 displays the results. Note that we have substantially less observations since we average the data over 3-year intervals to mitigate problems of measurement error. Comfortingly, the R\&D intensity performs better in these regressions than in level regressions. The R\&D intensity is positively correlated with the 90-10 and 50-10 male wage differential. The same holds for changes in the import intensity. Concerning the institutions, changes in benefit replacement rate and duration, union density or the minimum wage are negatively associated with changes in the 90-10 male wage differential. Changes in employment protection, union density and the minimum wage are negatively associated with changes in the 50-10 male wage differential. 


\subsection{System Estimation}

In an attempt to tackle the endogeneity of unemployment, we estimate a system where male wage inequality and unemployment are jointly determined. We estimate our basic equation (16) for male wage inequality together with an unemployment equation specified as in the literature on unemployment and institutions (Nickell et al., 2004). The system is of the form:

$$
\begin{aligned}
\log \left(\frac{w_{90}}{w_{10}}\right)_{i t} & =\theta_{0}+\theta_{1} v_{i t}+\gamma^{\prime} \mathbf{z}_{i t}+\boldsymbol{\vartheta}^{\prime} \mathbf{s}_{i t}+d_{i}+d_{t}+\varepsilon_{i t} \\
\log u_{i t} & =\alpha_{0}+\alpha_{1} \log u_{i t-1}+\boldsymbol{\beta}^{\prime} \mathbf{z}_{i t}+\delta^{\prime} \overline{\mathbf{s}}_{i t}+d_{i}+d_{t}+\eta_{i t}
\end{aligned}
$$

Identification is obtained through the different shocks affecting the wage inequality and unemployment equation. In particular, monetary shocks are assumed to influence unemployment but not wage inequality. The vector of institutions $z_{i t}$ is common to the wage inequality and the unemployment equation. The vector $\mathbf{s}_{i t}$ in the wage inequality equation contains as before $R D$ intensity and imp intensity. Following Nickell et al. (2004) the unemployment equation contains one lag of the dependent variable; the vector $\overline{\mathbf{s}}_{i t}$ in the unemployment equation contains a terms-of-trade shock $(T o T)$, the long-term real interest rate (long-term rate), a TFP shock calculated as the HodrickPrescott cyclical component of the Solow residual for each country (TFP), the acceleration in money supply (money), a labor demand shock calculated as the residual of by country employment regressions (lab.dem.). The data appendix contains further information about the construction and sources of these variables. While the TFP, terms-of-trade and labor demand shock reflect the forces of trade and technology in determining unemployment, the monetary shocks long - term rate and money do not have counterparts in the wage inequality equation. This is because there is little evidence that monetary variables affect directly wage dispersion while there is a long literature on the unemployment-inflation trade-off. Finally, both equations of the system contain country and time effects.

We estimate the system using 3SLS. Our results in column (1) of Table 6 indicate that the effects on institutions on male wage inequality are robust to treating unemployment as an endogenous variable. As in the previous regressions, $E P, B R R, U D$ and $M W$ are negatively associated with male wage inequality. Concerning the unemployment equation, similarly to the results obtained in Nickell et al. 2004 a higher bargaining coordination $C O$ is associated with lower unemployment 
whereas $B R R$ is positively correlated with unemployment. All other institutions are not significant. Also the effect of shocks on unemployment is in line with result reported in Nickell et al. (2004): the labor demand shock and the TFP shock have a strong negative effect, the terms-of-trade shocks has a positive effect and all other effects are rather unimportant.

Column (3) of Table 6 shows the estimates of system (17) using a SURE estimator. In this case we assume that both wage inequality and unemployment are determined by common macroeconomic shocks which are not controlled for in our specification. The results of column (3) confirm that $E P, B R R, U D$ and $M W$ are negatively associated with male wage inequality. Similarly to the 3SLS estimates, $C O$ is negatively correlated with unemployment whereas the opposite is the case for $B R R$.

\subsection{Simulations}

We now illustrate further how different institutional environments are associated with the wage differential. The simulations should be interpreted with care because, as mentioned above, measurement of institutions is imperfect. Table 7 presents three sets of simulations based on the coefficient estimates in column (1), Table 3, and the model with interactions column (4), Table 4. The first set of simulations calculates the percentage increase in the 90-10 differential correlated with one standard-deviation reduction in rigidity for each institutional dimension. This corresponds to a one standard-deviation reduction in each indicator (the standard deviations are shown in Table 2). A reduction of employment protection by one standard deviation turns out to be most important, being associated with a 19-20\% higher wage differential. Reducing the generosity of the unemployment benefit system in terms of size or duration by one standard deviation is associated with a 3\%-7\% and a 4\%-5\% higher wage differential, depending on whether the interactions of institutions are included. Finally, a reduction of one standard deviation of union density or the minimum wage is associated with an increase of the wage differential of 7\%-9\% and $6 \%$, respectively.

The second set of simulations in Table 7 shows the percentage increase in the 90-10 differential correlated with a change from the most rigid to the most flexible regulation in each institutional dimension. The values of the institutional indicators are shown in Table 10 and 11 in the Appendix. According to the coefficient estimates of column (1) in Table 3, a change from the most rigid employment protection legislation (Italy) to the most flexible one (US) is associated with an increase of the 90-10 differential of 60\%. The implied change in the 90-10 differential changes little if we use 
the coefficients of the model with interactions (column (4), Table 4) and we consider the change for a country with a low value of the minimum wage and a high value of the minimum wage. The same exercise can be done for the benefit replacement rate, union density and the minimum wage. The interactions play an important role for the size of the correlation of some indicators. For example, the positive correlation of lower union density and the wage differential is more than offset if bargaining coordination is higher. The role of unemployment benefits is much more important when the duration is longer. In both cases these results consistent with the literature on institutional interactions discussed above.

The third set of simulations in Table 7 shows the impact of the time effects for the specification with and without institution interactions. The time dummies capture the unobservable components common to all countries such as common supply and demand shocks. The numbers are obtained subtracting the value of the time dummy in the last year minus the dummy in the first year of the sample. In both cases the time effects are positively associated with the wage differential. The time effects are more important in the initial part of the sample 1973-1983 and much less important in the model with institution interactions. This is not surprising: the specification with interactions outperforms the baseline model in column (1), Table 3, so that a smaller part of the variation in the wage differential is accounted for by unobservable common components.

In Table 8 we simulate the correlation of the 90-10 differential predicted by our models if regulations were changed towards US levels in each country. The numbers are obtained using the coefficients estimates of column (1), Table 3, and of column (4), Table 4 and the average values of employment protection, benefit replacement ratios, benefit duration, union density and minimum wages for each country. ${ }^{13}$ Table 8 displays sizeable positive correlations of the wage differential: an increase between $14 \%$ and $67 \%$ for the baseline model and $28 \%$ and $87 \%$ in the specification with institution interactions. For example, the simulations based on the specification with institution interactions imply the largest correlation for the Netherlands, with an almost twice as large wage differential. This is because the Netherlands have more rigid institutions than the US for all five institutional measures. Instead, for example, France has a lower union density, and Germany, Italy and Sweden have no official minimum wage. Not surprisingly, Anglo-Saxon countries have the smallest positive correlations since their institutional environment is more similar to the US.

\footnotetext{
${ }^{13}$ We consider only the institutions which are significant in the regressions in column (1), Table 3, and column (4), Table 4.
} 
Finally, in Table 9 we compute the percentage change in the 90-10 log wage differential associated with changes in institutions from 1973 to 1999. We predict wage inequality using the coefficient estimates of column (1), Table 3, and of column (4), Table 4. We compare the fitted values holding institutions constant at the initial level with the fitted values obtained with time-varying institutions. The values in the table show the percentage difference between the two fitted series. The changes in institutions are associated with country-specific evolutions of wage inequality. Had institutions not changed since the 1970s, the 90-10 wage differential in France, for example, would be $14 \%$ higher than the actual value in the 1990s. We decompose this percentage change further, holding constant one institution at a time. We find that holding employment protection constant at the level in the 1970s is associated with $12 \%$ higher wage inequality in France in the 1990s. Moreover, the increase in the minimum wage accounts for a $2 \%$ lower wage inequality in the $1990 \mathrm{~s}$ while the decrease of union density alone contributes to $4 \%$ of higher wage inequality.

Similarly, had institutions remained the same as in the 1970s in Sweden, wage inequality would be $30 \%$ higher than the actual value in the 1990s. This is mainly associated with the increase in union density and in the benefit replacement ratio. The increase in union density alone accounts for a $8 \%$ lower wage inequality while the increase in the benefit replacement ratio contributes to $10 \%$ of lower wage inequality. In the US and the UK, instead, the decline in union density and in the minimum wage (US only), are associated with a higher wage inequality over time. Had all institutions stayed the same as in 1970s, wage inequality would be $4 \%$ lower in the 1990s in both the US and the UK. The decline in union density alone contributed to $3 \%$ of the increase of wage inequality in the US and to $5 \%$ of higher wage inequality in the UK. The decline in the minimum wage accounts for a $1 \%$ higher wage inequality in the US.

\section{Conclusion}

We have shown in a simple model of bilateral monopoly how labor market institutions affect labor demand, the surplus of firms and workers and thus the wage differential. Since institutions tend to affect unskilled more than skilled workers, they are associated with more compressed wage differentials. We find in particular that employment protection, unemployment benefit generosity and duration, union density and minimum wages are negatively correlated with the male wage differential. The variation of the male wage differential explained by institutions is at least as high 
as the amount explained by our trade and technology measures.

Of course, further research needs to elaborate on these findings in various dimensions. Since aggregate policies have different effects at the micro level (for example across industries), our aggregate perspective is clearly limited (see, for example, Heckman and Pages, 2003, for a comparison between the macro and micro estimates of the effect of institutions). Although the robustness of the insights of our broad perspective are confirmed by existing studies on the wage differential and some of the institutions at the micro level, further research is needed to be confident about the results especially for the institutions for which no such studies seem to be available: employment protection, unemployment benefits and the tax wedge.

Since in our estimations we can only provide a variance decomposition, it would be desirable in future research to explore the causal links between institutions and the wage differential. In particular, in such empirical analyses based on long time periods as our sample, institutions cannot be considered as fully exogenous. Deunionization or minimum wages might be at least partly endogenous to changes in trade and technology. Thus, the correlations of institutional changes and changes in the wage differential might very well be smaller if we were able to control for the endogeneity of institutions (see Acemoglu et al., 2001, on the interaction between technology and deunionization). 


\section{References}

[1] Abraham , Kathrine and Susanne Houseman (1995): "Earnings Inequality in Germany", in: Differences and Changes in Wage Structures, Freeman, Richard B. and Lawrence F. Katz (eds.), The University of Chicago Press, Chicago.

[2] Acemoglu, Daron (2003): "Cross-Country Inequality Trends", Economic Journal, vol. 113, F121-49.

[3] Acemoglu, Daron, Philippe Aghion and Giovanni L. Violante (2001): "Deunionization, Technical Change and Inequality", Carnegie-Rochester Conference Series on Public Policy, vol. 55, $229-64$.

[4] Alesina, Alberto and Roberto Perotti (1997): "The Welfare State and Competitiveness", American Economic Review, vol. 87, 921-39.

[5] Belot, Michelle. and Jan C. van Ours (2001): "Unemployment and Labor Market Institutions: an empirical analysis", Journal of Japanese and International Economics, vol. 15, 1-16.

[6] Belot, Michelle. and Jan C. van Ours (2004): "Does the Recent Success of Some OECD Countries in Lowering their Unemployment Rates Lie in the Clever Design of their Labour Market Reforms?", Oxford Economic Papers, forthcoming.

[7] Bertola, Giuseppe (1999): "Microeconomic Perspectives on Aggregate Labor Markets", in: Handbook of Labor Economics, Ashenfelter, Orley and David Card (eds.), vol. 3C, ch. 45, North Holland, Amsterdam.

[8] Bertola, Giuseppe, Francine D. Blau and Lawrence M. Kahn (2002): "Comparative Analysis of Labor Market Outcomes: lessons for the US from international long-run evidence", in: Krueger, Alan and Robert Solow (eds.), The Roaring Nineties: Can Full Employment Be Sustained?, Russell Sage and Century Foundations, 159-218.

[9] Bertola, Giuseppe, Francine D. Blau and Lawrence M. Kahn (2003): "Labor Market Institutions and Demographic Employment Patterns", European University Institute, mimeo.

[10] Bertola, Giuseppe and Richard Rogerson (1997): "Institutions and Labor Reallocation", European Economic Review, vol. 41, 1147-71. 
[11] Blanchard, Olivier J. and Lawrence H. Summers (1986): "Hysteresis and the European Unemployment Problem", in: Fischer, Stanley (ed.), NBER Macroeconomics Annual 1986, MIT Press, Cambridge.

[12] Blanchard, Olivier and Justin Wolfers (2000): "The Role of Shocks and Institutions in the Rise of European Unemployment: the aggregate evidence", Economic Journal, vol. 110, C1-33.

[13] Blau, Francine D. and Lawrence M. Kahn (1996): "International Differences in Male Wage Inequality: institutions versus market forces", Journal of Political Economy, vol. 104, 791-837.

[14] Blau, Francine D. and Lawrence M. Kahn (2004): "Do Cognitive Test Scores Explain Higher U.S. Wage Inequality?", CESIfo Working Paper No. 1139.

[15] Calmfors, Lars and John Driffill (1988): "Bargaining Structure, Corporatism and Macroeconomic Performance", Economic Policy, 6, 14-61.

[16] Card, David (2001): "The Effect of Unions on Wage Inequality in the U.S. Labor Market", Industrial and Labor Relations Review, vol. 54, 296-315.

[17] Card, David, Thomas Lemieux and W. Craig Riddell (2003): "Unionization and Wage Inequality: a comparative study of the US, UK, and Canada", NBER Working Paper No. W9473.

[18] Danthine, Jean-Pierre and Jennifer Hunt (1994): "Wage Bargaining Structure, Employment and Economic Integration", Economic Journal, vol. 104, 528-41.

[19] Daveri, Francesco and Guido Tabellini (2000): "Unemployment, Growth and Taxation in Industrial Countries", Economic Policy, 30, 47-104.

[20] Dickens, Richard, Stephen J. Machin and Alan Manning (1999): "The Effects of Minimum Wages on Employment: theory and evidence from Britain", Journal of Labor Economics, vol. $17,1-22$.

[21] Di Nardo, John, Nicole Fortin and Thomas Lemieux (1996): "Labor Market Institutions and the Distribution of Wages: a semi-parametric approach", Econometrica, vol. 64, 1001-44.

[22] Ebbinghaus, Bernhard and Jelle Visser (2000): Trade Unions in Western Europe since 1945, Macmillan. 
[23] Edin, Per-Anders and Bertil Holmlund (1995): "The Swedish Wage Structure: the rise and fall of solidarity wage policy?", in: Differences and Changes in Wage Structures, Freeman, Richard B. and Lawrence F. Katz (eds.), The University of Chicago Press, Chicago.

[24] Erickson, Chris and Andrea Ichino (1995): "Wage Differentials in Italy: market forces, institutions and inflation", in: Differences and Changes in Wage Structures, Freeman, Richard B. and Lawrence F. Katz (eds.), The University of Chicago Press, Chicago.

[25] Farber, Henry S. (1986): "The Analysis of Union Behavior", in: Handbook of Labor Economics, Ashenfelter, Orley and David Card (eds.), vol. 2, ch. 18, North Holland, Amsterdam.

[26] Freeman, Richard B. and Robert S. Gibbons (1995): "Getting Together and Breaking Apart: the decline of centralized collective bargaining", in: Differences and Changes in Wage Structures, Freeman, Richard B. and Lawrence F. Katz, eds., The University of Chicago Press, Chicago.

[27] Heckman, James and Carmes Pages (2003): "Law and Employment: lessons from Latin America and the Caribbean", NBER Working Paper No. 10129.

[28] Huber, Evelyne, Charles Ragin, and John D. Stephens (1997): Comparative Welfare States Data Set, Northwestern University and University of North Carolina.

[29] ILO (1997): World Labour Report 1997-98: Industrial Relations, Democracy and Social Stability, Geneva.

[30] Kahn, Lawrence M. (2000): "Wage Inequality, Collective Bargaining, and Relative Employment from 1985 to 1994: evidence from fifteen OECD countries", Review of Economics and Statistics, vol. 82, 564-79.

[31] Layard, Richard, Stephen Nickell and Richard Jackman (1991): Unemployment: Macroeconomic Performance and the Labour Market, Oxford University Press, Oxford.

[32] Lazear, Edward P. (1990): "Job Security Provisions and Employment", Quarterly Journal of Economics, vol. 105, 699-726.

[33] Lee, David S. (1999): "Wage Inequality in the United States during the 1980s: rising dispersion or falling minimum wage?", Quarterly Journal of Economics, vol. 114, 977-1023. 
[34] Leuven, Edwin, Hessel Oosterbeek and Hans van Ophem (2004): "Explaining International Differences in Male Skill Wage Differentials by Differences in Demand and Supply of Skill", Economic Journal, vol. 114, 466-86.

[35] Machin, Stephen J. (1997): "The Decline of Labour Market Institutions and the Rise in Wage Inequality in Britain", European Economic Review, Papers and Proceedings, vol. 41, 647-58.

[36] Machin, Stephen J. and John van Reenen (1998), "Technology and Changes in Skill Structure: evidence from seven OECD countries", Quarterly Journal of Economics, vol. 113, 1215-44.

[37] Manacorda, Marco (2004): "Can the Scala Mobile Explain the Fall and Rise of Earnings Inequality in Italy: a semiparametric analysis, 1977-93", Journal of Labor Economics, forthcoming.

[38] Nickell, Stephen and Brian Bell (1996): "Changes in the Distribution of Wages and Unemployment in OECD Countries", American Economic Review, Papers and Proceedings, vol. 86, $302-8$.

[39] Nickell, Stephen and Richard Layard (1999): "Labor Market Institutions and Economic Performance", in: Handbook of Labor Economics, Ashenfelter, Orley and David Card (eds.), vol. 3C, ch. 46, North Holland, Amsterdam.

[40] Nickell, Stephen, Luca Nunziata and Wolfgang Ochel (2004): "Unemployment in the OECD Since the 1960s. What Do We Know?", Economic Journal, forthcoming.

[41] Nunziata, Luca (2002): "Institutions and Wage Determination: a Multi-Country Approach", Nuffield College, University of Oxford, mimeo.

[42] Stole, Lars A. and Jeffrey Zwiebel (1996a): "Intra-Firm Bargaining under Non-Binding Contracts", Review of Economic Studies, vol. 63, 375-410.

[43] Stole, Lars A. and Jeffrey Zwiebel (1996b): "Organizational Design and Technology Choice under Intrafirm Bargaining", American Economic Review, vol. 86, 195-222.

[44] Teulings, Coen and Joop Hartog (1998): Corporatism or Competition? Labour Contracts, institutions and wage structures in international comparison, Cambridge University Press, Cambridge. 
[45] Topel, Robert H. (1994): "Regional Labor Markets and the Determinants of Wage Inequality", American Economic Review, Papers and Proceedings, vol. 84, 17-22.

[46] Visser, Jelle (1996): Unionisation Trends: The OECD Countries Union Membership File, University of Amsterdam, Centre for Research of European Societies and Labour Relations.

[47] Wallerstein, Michael (1990): “Centralized Bargaining and Wage Restraint", American Journal of Political Science, vol. 34, 982-1004.

[48] Wallerstein, Michael (1999): "Wage-Setting Institutions and Pay Inequality in Advanced Industrial Societies", American Journal of Political Science, vol. 43, 649-80. 
The following Appendices A and B and Table 10 and 11 are additional material for the referee

\section{Appendix A: Data Sources}

In this paper we have used data from the following sources:

Log wage differential (e.g. $l p 9010 m$ ): the OECD provides data on male wage dispersion. The measures for wage dispersion are the 90-10, the 90-50 and the 50-10 log differential of gross wages. We focus on male wage inequality since European countries have very different female labor force participation rates which might be related to the institutions we are looking at. Thus, including females would add important sample selection issues.

Relative unemployment rate: data on unemployment disaggregated by skill are not available for all countries and time periods on a comparable basis. The data on the relative unemployment rate of the skilled compared with the unskilled are obtained using the national aggregate series on unemployment rate provided by the OECD to construct $\log (u)$, and the national series of educational attainment provided by Angel de la Fuente and Rafael Domenech at

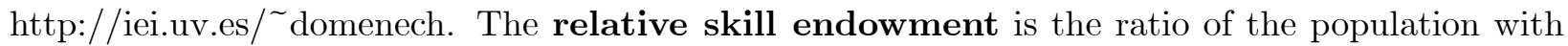
some college over the rest of the population which we use to calculate $\log ($ skill $)$.

Import intensity (imp intensity) and R\&D intensity ( $R D$ intensity): the OECD STAN database provides information on imports, $R \& D$ and value added in the manufacturing sector from 1973-2000. Using these data we can build our proxies for trade and technology using data on total manufacturing for imports, $\mathrm{R} \& \mathrm{D}$ and value added for all countries.

Government Expenditure per GDP (Gov.Exp./GDP), Female Labor Supply (Fem.Lab.Supply Employment share above age 24 (Empl. Share $>24)$ : these data are provided by the OECD National Accounts and Labor Force Statistics.

For further description of the following variables used in the unemployment equation see Nickell et al. (2004):

Labor Demand Shock (lab.dem.): this series consists of the residuals $\hat{\varepsilon}_{t}$ of the following 20 regressions by country:

$\log \left(E T_{t}\right)=\beta_{0}+\beta_{1} \log \left(E T_{t-1}\right)+\beta_{2} \log \left(E T_{t-2}\right)+\beta_{3} \log \left(E T_{t-3}\right)+\beta_{4} \log \left(Y Q_{t}\right)+\beta_{5} \log \left(W T P_{t}\right)+\varepsilon_{t}$

where ET is total employment and $Y Q$ and $W T P$ are real GDP and real labor cost at 1990 prices, respectively.

Real Interest Rate (long - term rate): the long-term real interest rate is constructed using long-term nominal interest rates and inflation from the OECD Economic Outlook database.

Acceleration in Money Supply (money): this measure is defined as $\Delta^{2} \ln (M S)$, where $M S$ is money supply from the OECD Economic Outlook database.

Terms of Trade Shock $(T o T):$ this series is equal to $I M P=\frac{M C}{Y C} \Delta\left\{\log \left(\frac{P_{m}}{P_{G}}\right)\right\}$, where $M C$ are imports at current prices, $Y C$ is GDP at current prices, $P_{m}$ is import price deflator and $P_{G}$ is GDP deflator at market prices, both with 1990 as base year.

TFP Shock $(T F P)$ : this series is calculated as the Hodrick-Prescott filtered cyclical component of the Solow residual for each country.

The data on institutions are the employment protection index, the size and duration of unemployment benefits, minimum wages, union density and coordination and tax wedges. We now present these data in some detail: 
Employment Protection (EP): Blanchard and Wolfers (2000) provide a time-varying employment protection indicator for the time period 1960-95, with one observation every 5 years. This series is built chaining OECD data with data from Lazear (1990). Notice that the OECD data, used from 1985 onwards, is constructed on the basis of a more extensive collection of employment protection dimensions compared with data used by Lazear. Our data set includes an interpolation of the Blanchard and Wolfers series, readjusted in the mean with range $\{0,2\}$ increasing with strictness of employment protection.

Net Union Density $(U D)$ : for non-European countries this variable is constructed as the ratio of total reported union members (gross minus retired and unemployed members), as reported in Visser (1996), over the number of wage and salaried employees, reported in Huber et al. (1997). The data are updated respectively using data from the Bureau of Labor Statistics (United States: 1994 and 1995), the ILO (1997) (Australia: 1995; New Zealand: 1994 and 1995; Canada: 1994 and 1995) and the Basic Survey on Labor Unions by the Japan Ministry of Health, Labor and Welfare (Japan: 1995).

The data for European countries except Sweden are reported in Ebbinghaus and Visser (2000) using the same criteria. Concerning Sweden, Ebbinghaus and Visser provide data on the gross density only. Therefore we use the same sources that we use for non-European countries, updating the series using the growth rate of gross density in 1995.

Bargaining Coordination $(C O)$ : this is an index with range $\{1,3\}$ constructed as an interpolation of OECD data on bargaining coordination. It is increasing in the degree of coordination in the bargaining process on the employers' as well as on the unions' side. The resulting series were matched with the data reported in Belot and van Ours (2004).

Benefit Replacement Ratio $(B R R)$ : the data is provided by the OECD with one observation every two years for each country in the sample. The data refer to the first year of unemployment benefits, averaged over family types of recipients, since in many countries benefits depend on family composition. The benefits are measured as a proportion of average earnings before tax.

Benefit Duration $(B D)$ : we constructed this index as a weighted average $B D=\alpha B R R_{2} / B R R_{1}$ $+(1-\alpha) B R R_{4} / B R R_{1}$, where $B R R_{1}$ is the unemployment benefit replacement rate received during the first year of unemployment, $B R R_{2}$ is the replacement rate received during the second and third year of unemployment and $B R R_{4}$ is the replacement rate received during the fourth and fifth year of unemployment. Note that we give more weight to the first ratio than to the second $(\alpha=0.6)$.

Tax Wedge $(T W)$ : the tax wedge is equal to the sum of the employment tax rate, the direct tax rate and the indirect tax rate: $T W=t 1+t 2+t 3$. The employment tax rate $t 1$ is calculated as $t 1=E C /(I E-E C)$, where $E C$ denotes the employers' total contributions and $I E$ denotes wages, salaries and social security contributions. The direct tax rate is defined as $t 2=D T / H C R$ where $D T$ is the amount of direct taxes and $H C R$ is the amount of households' current receipts. The indirect tax rate is defined as $t 3=(T X-S B) / C C$ where $T X$ are total indirect taxes, $S B$ subsidies, and $C C$ private final expenditures. All data come from London School of Economics CEP - OECD data base, updated using the same criteria.

Minimum Wage $(M I N W)$ : this is the ratio of the statutory minimum wage to the median wage in each country. It is provided by the OECD. 


\section{Appendix B: Proofs of Remark 1-3}

\section{Proof of Remark 1:}

The ratio of equations (7) and (8) within the same sector implies that

$$
\frac{\left(1+\tau_{h}+\lambda s_{h}\right) w_{h}}{\left(1+\tau_{l}+\lambda s_{l}\right) w_{l}}=\frac{\psi_{i}}{1-\psi_{i}} \sigma_{i}^{-1}
$$

or

$$
\frac{1-\psi_{i}}{\psi_{i}} \sigma_{i}=\frac{\left(1+\tau_{l}+\lambda s_{l}\right) w_{l}}{\left(1+\tau_{h}+\lambda s_{h}\right) w_{h}}
$$

Equation (A2) implies that

$$
\frac{1-\psi_{1}}{\psi_{1}} \sigma_{1}=\frac{1-\psi_{2}}{\psi_{2}} \sigma_{2}
$$

and thus

$$
\sigma_{1}=\frac{\psi_{1}}{\psi_{2}} \frac{1-\psi_{2}}{1-\psi_{1}} \sigma_{2}
$$

It follows from our assumption $\psi_{1}<\psi_{2}$ that $\sigma_{1}<\sigma_{2}$.

The ratio of equations (7) and (8) across sectors implies that

$$
\frac{\left(1+\tau_{h}+\lambda s_{h}\right) w_{h}}{\left(1+\tau_{l}+\lambda s_{l}\right) w_{l}}=\frac{p_{1} a_{1} \psi_{1} \sigma_{1}^{\psi_{1}-1}}{p_{2} a_{2}\left(1-\psi_{2}\right) \sigma_{2}^{\psi_{2}}} .
$$

Using equation (A3) we get

$$
\frac{\left(1+\tau_{h}+\lambda s_{h}\right) w_{h}}{\left(1+\tau_{l}+\lambda s_{l}\right) w_{l}}=\frac{p_{1}}{p_{2}} \frac{a_{1}}{a_{2}} \frac{\psi_{1}}{1-\psi_{2}}\left(\frac{\psi_{1}}{\psi_{2}}\right)^{\psi_{1}-1}\left(\frac{1-\psi_{2}}{1-\psi_{1}}\right)^{\psi_{1}-1} \sigma_{2}^{\psi_{1}-\psi_{2}-1}
$$

Equating the right-hand side of equation (A4) with the right-hand side of equation (A1) and rearranging we get

$$
\sigma_{2}=\left(\frac{p_{1}}{p_{2}} \frac{a_{1}}{a_{2}}\left(\frac{\psi_{1}}{\psi_{2}}\right)^{\psi_{1}}\left(\frac{1-\psi_{2}}{1-\psi_{1}}\right)^{\psi_{1}-1}\right)^{\frac{1}{\psi_{2}-\psi_{1}}} .
$$

Plugging this back into equation (A4) we find

$$
\frac{\left(1+\tau_{h}+\lambda s_{h}\right) w_{h}}{\left(1+\tau_{l}+\lambda s_{l}\right) w_{l}}=\left(\frac{p_{1}}{p_{2}}\right)^{\frac{1}{\psi_{1}-\psi_{2}}}\left(\frac{a_{1}}{a_{2}}\right)^{\frac{1}{\psi_{1}-\psi_{2}}}\left(\frac{\psi_{1}}{\psi_{2}}\right)^{\frac{\psi_{2}}{\psi_{1}-\psi_{2}}}\left(\frac{1-\psi_{2}}{1-\psi_{1}}\right)^{\frac{1-\psi_{1}}{\psi_{2}-\psi_{1}}}
$$

Multiplying by $\left(1+\tau_{h}\right) /\left(1+\tau_{l}\right)$ taking logs and noting that $\ln (1+x) \simeq x$ for small $x$, we get the expression in Remark 1

\section{Proof of Remark 2:}

Step 1: Derive $\varepsilon_{h} / \varepsilon_{l}$.

Using equations (3) and (10) we find that

$$
\varepsilon_{h} \equiv \frac{\partial \Omega}{\partial w_{h}} \frac{w_{h}}{\Omega}=\frac{\xi \frac{\left(1-\rho_{h}\right)}{r+\lambda u_{h}^{-1}}}{\xi \frac{\left(1-\rho_{h}\right) w_{h}}{r+\lambda u_{h}^{-1}}+\frac{\left(1-\rho_{l}\right) w_{l}}{r+\lambda u_{l}^{-1}}} w_{h} .
$$


Similarly,

$$
\varepsilon_{l} \equiv \frac{\partial \Omega}{\partial w_{l}} \frac{w_{l}}{\Omega}=\frac{\frac{\left(1-\rho_{l}\right)}{r+\lambda u_{l}^{-1}}}{\xi \frac{\left(1-\rho_{h}\right) w_{h}}{r+\lambda u_{h}^{-1}}+\frac{\left(1-\rho_{l}\right) w_{l}}{r+\lambda u_{l}^{-1}}} w_{l}
$$

Thus,

$$
\frac{\varepsilon_{h}}{\varepsilon_{l}}=\xi \frac{1-\rho_{h}}{1-\rho_{l}} \frac{r+\lambda u_{l}^{-1}}{r+\lambda u_{h}^{-1}} \frac{w_{h}}{w_{l}} .
$$

Step 2: Derive the wage differential.

Plugging $\varepsilon_{h} / \varepsilon_{l}$ and (12) into (11) and rearranging, we get

$$
\frac{w_{h}}{w_{l}}=\xi^{-1} \frac{1+\tau_{l}-r s_{l}}{1+\tau_{l}+\lambda s_{l}} \frac{1+\tau_{h}+\lambda s_{h}}{1+\tau_{h}-r s_{h}} \frac{1-\rho_{l}}{1-\rho_{h}} \frac{r+\lambda u_{h}^{-1}}{r+\lambda u_{l}^{-1}} \frac{\psi_{1}+\frac{a_{2}}{a_{1}} \frac{p_{2}}{p_{1}} \frac{q_{2}}{q_{1}} \psi_{2}}{\left(1-\psi_{1}\right)+\frac{a_{2}}{a_{1}} \frac{p_{2}}{p_{1}} \frac{q_{2}}{q_{1}}\left(1-\psi_{2}\right)} .
$$

Multiplying by $\left(1+\tau_{h}\right) /\left(1+\tau_{l}\right)$, takings logs and using again that $\ln (1+x) \simeq x$ for small $x$, we get the expression for the log wage differential in Remark 2. It is straightforward to show that $\partial \pi(\cdot) / \partial\left(a_{2} / a_{1}\right)>0$ and $\partial \pi(\cdot) / \partial\left(p_{2} / p_{1}\right)>0$ if $\psi_{2}>\psi_{1}$ as we have assumed.

\section{Proof of Remark 3:}

Equation (15) implies that the expression for $\varepsilon_{h} / \varepsilon_{l}$ changes to

$$
\frac{\varepsilon_{h}}{\varepsilon_{l}}=\xi \frac{1-\rho_{h}}{1-\rho_{l}} \frac{r+\lambda u_{l}^{-1}}{r+\lambda u_{h}^{-1}} \frac{1+\frac{\lambda}{r u_{h}+\lambda} \zeta_{h} \eta_{h}}{1+\frac{\lambda}{r u_{l}+\lambda} \zeta_{l} \eta_{l}} \frac{w_{h}}{w_{l}} .
$$

It immediately follows that the additional term in the wage differential is

$$
\frac{1+\frac{\lambda}{r u_{l}+\lambda} \zeta_{l} \eta_{l}}{1+\frac{\lambda}{r u_{h}+\lambda} \zeta_{h} \eta_{h}}
$$

where the wage differential is compressed if

$$
1+\frac{\lambda}{r u_{l}+\lambda} \zeta_{l} \eta_{l}<1+\frac{\lambda}{r u_{h}+\lambda} \zeta_{h} \eta_{h} .
$$

Using the definition of $u_{k}$ and $\partial u_{k} / \partial k=-\bar{k}^{-1}, k=h, l, \eta_{k}=-1$ for Cobb-Douglas technology and rearranging, we get the inequality in Remark 3 


\begin{tabular}{|cccccc|}
\hline & Nobs & Mean & Std.Deviation & Min & Max \\
\cline { 2 - 6 } Wage differential: w90/w10 & 175 & 2.988 & 0.672 & 2.020 & 4.752 \\
Unemployment rate & 175 & 6.647 & 3.293 & 1.300 & 16.800 \\
Skill ratio & 175 & 0.304 & 0.210 & 0.059 & 1.126 \\
Unemp.rate * Skill Ratio & 175 & 2.110 & 1.880 & 0.146 & 9.672 \\
Employment protection indicator & 175 & 0.963 & 0.611 & 0.100 & 2.000 \\
Benefit replacement ratio & 175 & 0.414 & 0.196 & 0.010 & 0.821 \\
Benefit duration & 175 & 0.349 & 0.302 & 0.000 & 1.023 \\
Tax wedge & 175 & 0.518 & 0.144 & 0.243 & 0.831 \\
Union coordination indicator & 175 & 1.922 & 0.698 & 1.000 & 3.000 \\
Net union density & 175 & 0.397 & 0.224 & 0.099 & 0.886 \\
Minimum wage indicator & 175 & 0.221 & 0.237 & 0.000 & 0.646 \\
R\&D intensity & 175 & 0.061 & 0.030 & 0.010 & 0.133 \\
Import intensity & 175 & 0.071 & 0.039 & 0.012 & 0.217 \\
\hline
\end{tabular}

Notes: For the definition and data sources of the variables see the data appendix.

Table 2: Summary statistics 


\begin{tabular}{|c|c|c|c|c|c|}
\hline & $\begin{array}{c}(1) \\
\text { lp9010m }\end{array}$ & $\begin{array}{c}(2) \\
\operatorname{lp} 9010 \mathrm{~m}\end{array}$ & $\begin{array}{c}(3) \\
\operatorname{lp} 9010 \mathrm{~m}\end{array}$ & $\begin{array}{c}(4) \\
\text { lp9050m }\end{array}$ & $\begin{array}{c}(5) \\
\operatorname{lp} 5010 \mathrm{~m}\end{array}$ \\
\hline $\mathrm{EP}$ & $\begin{array}{c}\mathbf{- 0 . 2 9 9} \\
(7.27)\end{array}$ & $\begin{array}{c}\mathbf{- 0 . 2 6 1} \\
(5.90)\end{array}$ & & $\begin{array}{c}\mathbf{- 0 . 1 7 4} \\
(7.39)\end{array}$ & $\begin{array}{c}\mathbf{- 0 . 1 3 0} \\
(6.09)\end{array}$ \\
\hline BRR & $\begin{array}{c}\mathbf{- 0 . 1 8 9} \\
(2.99)\end{array}$ & $\begin{array}{c}-0.229 \\
(4.47)\end{array}$ & & $\begin{array}{c}-\mathbf{0 . 1 1 5} \\
(3.45)\end{array}$ & $\begin{array}{c}-\mathbf{0 . 0 7 3} \\
(2.05)\end{array}$ \\
\hline $\mathrm{BD}$ & $\begin{array}{c}-\mathbf{0 . 1 6 3} \\
(2.22)\end{array}$ & $\begin{array}{c}-\mathbf{0 . 2 6 6} \\
(4.45)\end{array}$ & & $\begin{array}{c}-\mathbf{0 . 0 9 6} \\
(2.59)\end{array}$ & $\begin{array}{c}-\mathbf{0 . 0 6 8} \\
(1.56)\end{array}$ \\
\hline TW & $\begin{array}{c}-\mathbf{0 . 0 4 6} \\
(0.49)\end{array}$ & $\begin{array}{c}-\mathbf{0 . 2 5 2} \\
(3.20)\end{array}$ & & $\begin{array}{l}\mathbf{0 . 0 0 0} \\
(0.01)\end{array}$ & $\begin{array}{c}-\mathbf{0 . 0 3 9} \\
(0.68)\end{array}$ \\
\hline $\mathrm{CO}$ & $\begin{array}{c}-\mathbf{0 . 0 0 2} \\
(0.06)\end{array}$ & $\begin{array}{l}\mathbf{0 . 0 9 3} \\
(3.19)\end{array}$ & & $\begin{array}{l}\mathbf{0 . 0 2 8} \\
(1.66)\end{array}$ & $\begin{array}{c}-\mathbf{0 . 0 3 0} \\
(1.73)\end{array}$ \\
\hline UD & $\begin{array}{c}\mathbf{- 0 . 4 2 9} \\
(3.92)\end{array}$ & $\begin{array}{c}\mathbf{- 0 . 5 8 4} \\
(6.59)\end{array}$ & & $\begin{array}{c}-\mathbf{0 . 3 0 3} \\
(5.24)\end{array}$ & $\begin{array}{c}-\mathbf{0 . 1 4 0} \\
(2.17)\end{array}$ \\
\hline MW & $\begin{array}{c}-\mathbf{0 . 2 6 8} \\
(5.24)\end{array}$ & $\begin{array}{c}-\mathbf{0 . 1 6 1} \\
(3.56)\end{array}$ & & $\begin{array}{c}-\mathbf{0 . 1 4 5} \\
(6.22)\end{array}$ & $\begin{array}{c}\mathbf{- 0 . 1 2 1} \\
(3.56)\end{array}$ \\
\hline $\log (\mathrm{u})$ & $\begin{array}{c}-\mathbf{0 . 0 1 2} \\
(0.46)\end{array}$ & $\begin{array}{c}\mathbf{- 0 . 0 0 8} \\
(0.29)\end{array}$ & & $\begin{array}{c}-0.060 \\
(4.65)\end{array}$ & $\begin{array}{l}\mathbf{0 . 0 4 0} \\
(2.60)\end{array}$ \\
\hline $\log ($ skill $)$ & $\begin{array}{l}\mathbf{0 . 1 7 6} \\
(2.51)\end{array}$ & $\begin{array}{l}\mathbf{0 . 3 9 5} \\
(5.68)\end{array}$ & & $\begin{array}{l}\mathbf{0 . 0 6 2} \\
(1.63)\end{array}$ & $\begin{array}{l}\mathbf{0 . 1 0 9} \\
(2.76)\end{array}$ \\
\hline $\log (\mathrm{u}) \log ($ skill $)$ & $\begin{array}{l}\mathbf{0 . 0 1 4} \\
(0.99)\end{array}$ & $\begin{array}{l}\mathbf{0 . 0 2 9} \\
(1.50)\end{array}$ & & $\begin{array}{c}-\mathbf{0 . 0 3 6} \\
(4.96)\end{array}$ & $\begin{array}{l}\mathbf{0 . 0 4 3} \\
(5.00)\end{array}$ \\
\hline RD intensity & $\begin{array}{c}\mathbf{- 1 . 0 2 5} \\
(2.62)\end{array}$ & $\begin{array}{l}\mathbf{0 . 4 6 9} \\
(1.28)\end{array}$ & & $\begin{array}{c}-\mathbf{0 . 5 3 0} \\
(2.60)\end{array}$ & $\begin{array}{c}-\mathbf{0 . 4 3 2} \\
(1.90)\end{array}$ \\
\hline Imp intensity & $\begin{array}{l}\mathbf{2 . 0 4 8} \\
(3.84)\end{array}$ & $\begin{array}{l}\mathbf{0 . 3 7 2} \\
(0.82)\end{array}$ & & $\begin{array}{l}\mathbf{1 . 0 8 1} \\
(3.99)\end{array}$ & $\begin{array}{l}\mathbf{0 . 9 2 7} \\
(3.01)\end{array}$ \\
\hline Gov.Exp./GDP & & $\begin{array}{c}-\mathbf{0 . 7 0 0} \\
(2.41)\end{array}$ & & & \\
\hline Fem. Lab. Supply & & $\begin{array}{c}\mathbf{- 1 . 1 2 7} \\
(2.79)\end{array}$ & & & \\
\hline Empl. Share $>24$ & & $\begin{array}{l}\mathbf{1 . 5 3 3} \\
(6.98)\end{array}$ & & & \\
\hline Observations & 175 & 160 & 175 & 175 & 175 \\
\hline Countries & 11 & 11 & 11 & 11 & 11 \\
\hline RMSE & 0.0380 & 0.0329 & 0.0836 & 0.0199 & 0.0237 \\
\hline $\mathrm{R} 2$ & 0.9702 & 0.9799 & 0.9354 & 0.9601 & 0.9756 \\
\hline Country dummies & Yes & Yes & Yes & Yes & Yes \\
\hline Year dummies & Yes & Yes & Yes & Yes & Yes \\
\hline
\end{tabular}

Notes: The dependent variables are the 90-10, the 90-50 and the 50-10 log differential of gross male wages. The estimation method includes fixed effects and corrects for country heteroskedasticity. The institutional variables are union density (UD), benefit replacement ratio $(\mathrm{BRR})$, tax wedge $(\mathrm{TW})$, minimum wage $(\mathrm{MW})$, the unemployment rate $(\log (\mathrm{u}))$, the ratio of the skilled over the unskilled $(\log ($ skill)). The trade and technology shocks (imp intensity and RD intensity) are proportions (range 0-1). Employment protection (EP) and co-ordination (CO) are indices (ranges 0-2, 1-3 respectively). Absolute value of $\mathrm{z}$ statistics in parentheses.

Table 3: Baseline models 


\begin{tabular}{|c|c|c|c|c|c|c|}
\hline & $\begin{array}{c}(1) \\
\operatorname{lp} 9010 \mathrm{~m}\end{array}$ & $\begin{array}{c}(2) \\
\operatorname{lp} 9010 \mathrm{~m}\end{array}$ & $\begin{array}{c}(3) \\
\operatorname{lp} 9010 \mathrm{~m}\end{array}$ & $\begin{array}{c}(4) \\
\operatorname{lp} 9010 \mathrm{~m}\end{array}$ & $\begin{array}{c}(5) \\
\operatorname{lp} 9050 \mathrm{~m}\end{array}$ & $\begin{array}{c}(6) \\
\operatorname{lp} 5010 \mathrm{~m}\end{array}$ \\
\hline $\mathrm{EP}$ & $\begin{array}{c}\mathbf{- 0 . 4 2 0} \\
(9.20)\end{array}$ & $\begin{array}{c}\mathbf{- 0 . 3 2 9} \\
(8.84)\end{array}$ & $\begin{array}{c}\mathbf{- 0 . 2 5 7} \\
(7.11)\end{array}$ & $\begin{array}{c}\mathbf{- 0 . 2 9 9} \\
(7.72)\end{array}$ & $\begin{array}{c}\mathbf{- 0 . 1 6 8} \\
(8.01)\end{array}$ & $\begin{array}{c}\mathbf{- 0 . 1 4 5} \\
(5.88)\end{array}$ \\
\hline BRR & $\begin{array}{c}-\mathbf{0 . 2 1 0} \\
(3.41)\end{array}$ & $\begin{array}{c}\mathbf{- 0 . 2 8 8} \\
(5.26)\end{array}$ & $\begin{array}{c}-\mathbf{0 . 3 1 1} \\
(5.07)\end{array}$ & $\begin{array}{c}-\mathbf{0 . 4 2 6} \\
(7.98)\end{array}$ & $\begin{array}{c}-\mathbf{0 . 2 0 1} \\
(7.13)\end{array}$ & $\begin{array}{c}\mathbf{- 0 . 2 2 6} \\
(6.71)\end{array}$ \\
\hline $\mathrm{BD}$ & $\begin{array}{c}-\mathbf{0 . 1 1 2} \\
(1.62)\end{array}$ & $\begin{array}{c}-\mathbf{0 . 1 3 1} \\
(1.93)\end{array}$ & $\begin{array}{c}-\mathbf{0 . 2 5 2} \\
(3.70)\end{array}$ & $\begin{array}{c}\mathbf{- 0 . 1 8 2} \\
(3.01)\end{array}$ & $\begin{array}{c}-\mathbf{0 . 0 7 2} \\
(2.32)\end{array}$ & $\begin{array}{c}-\mathbf{0 . 1 1 3} \\
(3.02)\end{array}$ \\
\hline TW & $\begin{array}{l}\mathbf{0 . 0 6 7} \\
(0.67)\end{array}$ & $\begin{array}{c}\mathbf{- 0 . 0 3 3} \\
(0.41)\end{array}$ & $\begin{array}{l}\mathbf{0 . 0 8 9} \\
(1.00)\end{array}$ & $\begin{array}{l}\mathbf{0 . 0 9 4} \\
(1.31)\end{array}$ & $\begin{array}{l}\mathbf{0 . 0 0 8} \\
(0.21)\end{array}$ & $\begin{array}{l}\mathbf{0 . 0 8 8} \\
(1.78)\end{array}$ \\
\hline $\mathrm{CO}$ & $\begin{array}{l}\mathbf{0 . 0 0 4} \\
(0.12)\end{array}$ & $\begin{array}{l}\mathbf{0 . 0 2 4} \\
(0.85)\end{array}$ & $\begin{array}{c}-\mathbf{0 . 0 1 1} \\
(0.40)\end{array}$ & $\begin{array}{l}\mathbf{0 . 0 2 5} \\
(1.06)\end{array}$ & $\begin{array}{l}\mathbf{0 . 0 5 8} \\
(4.07)\end{array}$ & $\begin{array}{c}-\mathbf{0 . 0 2 3} \\
(1.74)\end{array}$ \\
\hline UD & $\begin{array}{c}-0.499 \\
(4.64)\end{array}$ & $\begin{array}{c}-\mathbf{0 . 3 1 2} \\
(3.17)\end{array}$ & $\begin{array}{c}-\mathbf{0 . 4 2 1} \\
(4.07)\end{array}$ & $\begin{array}{c}-\mathbf{0 . 2 6 0} \\
(2.84)\end{array}$ & $\begin{array}{c}-\mathbf{0 . 2 0 8} \\
(4.22)\end{array}$ & $\begin{array}{c}-\mathbf{0 . 0 9 1} \\
(1.66)\end{array}$ \\
\hline MW & $\begin{array}{c}-\mathbf{0 . 6 3 3} \\
(6.47)\end{array}$ & $\begin{array}{c}\mathbf{- 0 . 2 0 5} \\
(3.91)\end{array}$ & $\begin{array}{c}-0.246 \\
(4.96)\end{array}$ & $\begin{array}{c}-\mathbf{0 . 1 8 0} \\
(1.89)\end{array}$ & $\begin{array}{c}\mathbf{- 0 . 0 9 7} \\
(2.17)\end{array}$ & $\begin{array}{c}-\mathbf{0 . 0 9 8} \\
(1.53)\end{array}$ \\
\hline EPMW & $\begin{array}{c}-\mathbf{0 . 6 7 9} \\
(4.48)\end{array}$ & & & $\begin{array}{c}-\mathbf{0 . 0 0 9} \\
(0.07)\end{array}$ & $\begin{array}{l}\mathbf{0 . 0 0 9} \\
(0.13)\end{array}$ & $\begin{array}{c}-\mathbf{0 . 0 5 8} \\
(0.64)\end{array}$ \\
\hline UDCO & & $\begin{array}{l}\mathbf{0 . 6 7 3} \\
(7.62)\end{array}$ & & $\begin{array}{l}\mathbf{0 . 6 6 9} \\
(7.70)\end{array}$ & $\begin{array}{l}\mathbf{0 . 4 1 9} \\
(9.16)\end{array}$ & $\begin{array}{l}\mathbf{0 . 2 5 5} \\
(4.74)\end{array}$ \\
\hline $\mathrm{BRBD}$ & & & $\begin{array}{c}\mathbf{- 0 . 9 3 4} \\
(7.16)\end{array}$ & $\begin{array}{c}\mathbf{- 0 . 8 4 4} \\
(6.84)\end{array}$ & $\begin{array}{c}\mathbf{- 0 . 2 2 4} \\
(3.45)\end{array}$ & $\begin{array}{c}\mathbf{- 0 . 5 8 0} \\
(7.18)\end{array}$ \\
\hline $\log (u)$ & $\begin{array}{c}\mathbf{- 0 . 0 0 8} \\
(0.31)\end{array}$ & $\begin{array}{c}\mathbf{- 0 . 0 3 4} \\
(1.54)\end{array}$ & $\begin{array}{l}\mathbf{0 . 0 2 6} \\
(1.04)\end{array}$ & $\begin{array}{c}-\mathbf{0 . 0 0 6} \\
(0.28)\end{array}$ & $\begin{array}{c}\mathbf{- 0 . 0 5 8} \\
(5.18)\end{array}$ & $\begin{array}{l}\mathbf{0 . 0 4 9} \\
(3.69)\end{array}$ \\
\hline $\log ($ skill $)$ & $\begin{array}{l}\mathbf{0 . 0 9 5} \\
(1.36)\end{array}$ & $\begin{array}{l}\mathbf{0 . 2 7 3} \\
(4.62)\end{array}$ & $\begin{array}{c}-\mathbf{0 . 0 0 5} \\
(0.08)\end{array}$ & $\begin{array}{l}\mathbf{0 . 1 2 5} \\
(2.12)\end{array}$ & $\begin{array}{l}\mathbf{0 . 0 9 1} \\
(2.89)\end{array}$ & $\begin{array}{l}\mathbf{0 . 0 3 7} \\
(1.06)\end{array}$ \\
\hline $\log (\mathrm{u}) \log ($ skill $)$ & $\begin{array}{l}\mathbf{0 . 0 1 4} \\
(0.98)\end{array}$ & $\begin{array}{c}-\mathbf{0 . 0 2 1} \\
(1.57)\end{array}$ & $\begin{array}{l}\mathbf{0 . 0 3 6} \\
(2.52)\end{array}$ & $\begin{array}{c}-\mathbf{0 . 0 0 0} \\
(0.01)\end{array}$ & $\begin{array}{c}-\mathbf{0 . 0 4 5} \\
(7.05)\end{array}$ & $\begin{array}{l}\mathbf{0 . 0 4 1} \\
(5.11)\end{array}$ \\
\hline RD intensity & $\begin{array}{c}-\mathbf{- 0 . 3 6 8} \\
(0.93)\end{array}$ & $\begin{array}{c}-\mathbf{0 . 2 3 3} \\
(0.69)\end{array}$ & $\begin{array}{l}\mathbf{0 . 0 7 2} \\
(0.18)\end{array}$ & $\begin{array}{l}\mathbf{0 . 7 7 4} \\
(2.34)\end{array}$ & $\begin{array}{l}\mathbf{0 . 1 5 9} \\
(0.91)\end{array}$ & $\begin{array}{l}\mathbf{0 . 6 3 7} \\
(3.07)\end{array}$ \\
\hline Imp intensity & $\begin{array}{l}\mathbf{2 . 2 9 7} \\
(4.24) \\
\end{array}$ & $\begin{array}{l}\mathbf{1 . 3 9 0} \\
(2.79) \\
\end{array}$ & $\begin{array}{l}\mathbf{2 . 0 6 2} \\
(3.99) \\
\end{array}$ & $\begin{array}{l}1.402 \\
(2.97) \\
\end{array}$ & $\begin{array}{r}\mathbf{0 . 7 3 3} \\
(3.22) \\
\end{array}$ & $\begin{array}{r}\mathbf{0 . 7 6 7} \\
(2.69) \\
\end{array}$ \\
\hline Observations & 175 & 175 & 175 & 175 & 175 & 175 \\
\hline Countries & 11 & 11 & 11 & 11 & 11 & 11 \\
\hline RMSE & 0.0364 & 0.0361 & 0.0347 & 0.0320 & 0.0176 & 0.0206 \\
\hline $\mathrm{R} 2$ & 0.9727 & 0.9738 & 0.9753 & 0.9792 & 0.9697 & 0.9818 \\
\hline Country dummies & Yes & Yes & Yes & Yes & Yes & Yes \\
\hline Year dummies & Yes & Yes & Yes & Yes & Yes & Yes \\
\hline
\end{tabular}

Notes: See the notes of Table 2. When interactions are included, the variables are set as deviations from the mean, so the interactions take the value zero at the sample mean. Absolute value of $\mathrm{z}$ statistics in parentheses.

Table 4: Baseline models with interactions 


\begin{tabular}{|c|c|c|c|c|}
\hline & $\begin{array}{c}(1) \\
\text { dlp9010m }\end{array}$ & $\begin{array}{c}(5) \\
\text { dlp9010m }\end{array}$ & $\begin{array}{c}(6) \\
\text { dlp9050m }\end{array}$ & $\begin{array}{c}(7) \\
\text { dlp5010m }\end{array}$ \\
\hline DEP & $\begin{array}{c}\mathbf{- 0 . 0 6 5} \\
(1.42)\end{array}$ & & $\begin{array}{c}\mathbf{- 0 . 0 0 2} \\
(0.05)\end{array}$ & $\begin{array}{c}-\mathbf{- 0 . 0 5 2} \\
(2.05)\end{array}$ \\
\hline DBRR & $\begin{array}{c}\mathbf{- 0 . 1 6 7} \\
(2.15)\end{array}$ & & $\begin{array}{c}\mathbf{- 0 . 1 5 2} \\
(3.08)\end{array}$ & $\begin{array}{l}\mathbf{0 . 0 1 0} \\
(0.18)\end{array}$ \\
\hline DBD & $\begin{array}{c}\mathbf{- 0 . 1 3 9} \\
(2.13)\end{array}$ & & $\begin{array}{c}-\mathbf{0 . 0 8 1} \\
(1.71)\end{array}$ & $\begin{array}{c}-\mathbf{0 . 0 5 3} \\
(1.12)\end{array}$ \\
\hline DTW & $\begin{array}{r}\mathbf{0 . 0 8 0} \\
(0.90)\end{array}$ & & $\begin{array}{c}-\mathbf{0 . 0 0 1} \\
(0.01)\end{array}$ & $\begin{array}{c}-\mathbf{0 . 0 3 3} \\
(0.37)\end{array}$ \\
\hline $\mathrm{DCO}$ & $\begin{array}{c}-\mathbf{0 . 0 1 2} \\
(0.38)\end{array}$ & & $\begin{array}{c}-\mathbf{0 . 0 0 2} \\
(0.08)\end{array}$ & $\begin{array}{c}-\mathbf{0 . 0 1 2} \\
(0.51)\end{array}$ \\
\hline DUD & $\begin{array}{c}\mathbf{- 0 . 7 2 5} \\
(3.23)\end{array}$ & & $\begin{array}{c}-\mathbf{0 . 3 2 3} \\
(2.21)\end{array}$ & $\begin{array}{c}-\mathbf{0 . 3 3 1} \\
(2.02)\end{array}$ \\
\hline DMW & $\begin{array}{c}\mathbf{- 0 . 0 9 0} \\
(2.11)\end{array}$ & & $\begin{array}{r}-0.027 \\
(1.00)\end{array}$ & $\begin{array}{c}-\mathbf{0 . 0 6 6} \\
(3.13)\end{array}$ \\
\hline $\operatorname{Dlog}(u)$ & $\begin{array}{l}\mathbf{0 . 0 4 3} \\
(2.24)\end{array}$ & & $\begin{array}{c}-\mathbf{0 . 0 1 9} \\
(1.30)\end{array}$ & $\begin{array}{l}\mathbf{0 . 0 5 6} \\
(3.41)\end{array}$ \\
\hline Dlog(skill) & $\begin{array}{l}\mathbf{0 . 0 5 5} \\
(0.50)\end{array}$ & & $\begin{array}{l}\mathbf{0 . 0 4 1} \\
(0.54)\end{array}$ & $\begin{array}{l}\mathbf{0 . 0 2 0} \\
(0.24)\end{array}$ \\
\hline Dlog(u)Dlog(skill) & $\begin{array}{l}\mathbf{0 . 0 4 0} \\
(3.21)\end{array}$ & & $\begin{array}{c}-\mathbf{0 . 0 2 1} \\
(2.10)\end{array}$ & $\begin{array}{l}\mathbf{0 . 0 5 6} \\
(5.55)\end{array}$ \\
\hline RD intensity & $\begin{array}{l}\mathbf{1 . 1 9 4} \\
(3.45)\end{array}$ & & $\begin{array}{l}\mathbf{0 . 2 2 9} \\
(1.11)\end{array}$ & $\begin{array}{l}\mathbf{1 . 0 4 1} \\
(4.78)\end{array}$ \\
\hline DImp intensity & $\begin{array}{l}\mathbf{1 . 2 1 0} \\
(3.82)\end{array}$ & & $\begin{array}{l}\mathbf{0 . 3 0 6} \\
(0.97)\end{array}$ & $\begin{array}{l}\mathbf{0 . 8 9 9} \\
(2.90)\end{array}$ \\
\hline Observations & 60 & 60 & 60 & 60 \\
\hline Countries & 11 & 11 & 11 & 11 \\
\hline RMSE & 0.0250 & 0.0384 & 0.0171 & 0.0155 \\
\hline $\mathrm{R} 2$ & 0.5652 & 0.3228 & 0.3719 & 0.9633 \\
\hline Country dummies & Yes & Yes & Yes & Yes \\
\hline Year dummies & Yes & Yes & Yes & Yes \\
\hline
\end{tabular}

Notes: The dependent variables are time differences in the 90-10, the 90-50 and the 50-10 log differential of gross male wages averaged over three years periods. The estimation method includes fixed effects and corrects for country heteroskedasticity. The variables are the time difference in union density (DUD), benefit replacement ratio (DBRR), employment tax rate (DTW), minimum wage (DMW), the unemployment rate $\operatorname{Dlog}(\mathrm{u})$, the ratio of the skilled versus the unskilled (Dlogskill) and the trade and technology shocks (Dimpintensity and RDintensity). Employment protection (DEP) and co-ordination (DCO) are time differences in the indices (ranges 0-2, 1-3 respectively). Absolute value of $\mathrm{z}$ statistics in parentheses.

Table 5: Baseline models in differences 


\begin{tabular}{|c|c|c|c|c|}
\hline & \multicolumn{2}{|c|}{$3 \mathrm{SLS}$} & \multicolumn{2}{|c|}{ SURE } \\
\hline & (1) & $(2)$ & $(3)$ & $(4)$ \\
\hline & lp9010m & $\log (u)$ & lp9010m & $\log (u)$ \\
\hline $\log (\mathrm{u})$ & $\begin{array}{c}\mathbf{- 0 . 0 4 0} \\
(1.02)\end{array}$ & & & \\
\hline $\log ($ skill $)$ & 0.094 & & 0.125 & \\
\hline & $(1.18)$ & & $(1.69)$ & \\
\hline $\log (u) \log ($ skill $)$ & 0.010 & & 0.027 & \\
\hline & $(0.48)$ & & $(2.97)$ & \\
\hline EP & -0.310 & -0.130 & -0.294 & -0.127 \\
\hline & $(7.54)$ & $(0.89)$ & $(7.56)$ & $(0.87)$ \\
\hline BRR & -0.118 & 0.363 & -0.125 & 0.351 \\
\hline & $(1.77)$ & $(1.76)$ & $(1.86)$ & $(1.70)$ \\
\hline $\mathrm{BD}$ & -0.095 & 0.069 & -0.111 & 0.054 \\
\hline & $(1.25)$ & $(0.32)$ & $(1.47)$ & $(0.25)$ \\
\hline TT & -0.102 & -0.102 & -0.085 & -0.091 \\
\hline & $(0.87)$ & $(0.28)$ & $(0.73)$ & $(0.25)$ \\
\hline $\mathrm{CO}$ & -0.015 & -0.176 & -0.006 & -0.170 \\
\hline & $(0.46)$ & $(2.05)$ & $(0.20)$ & $(1.98)$ \\
\hline UD & -0.378 & 0.202 & -0.417 & 0.197 \\
\hline & $(3.01)$ & $(0.57)$ & $(3.44)$ & $(0.55)$ \\
\hline MW & -0.254 & 0.387 & -0.259 & 0.386 \\
\hline & $(4.82)$ & $(1.10)$ & $(4.88)$ & $(1.09)$ \\
\hline RD intensity & -0.898 & & -1.147 & \\
\hline & $(1.98)$ & & $(2.92)$ & \\
\hline Imp intensity & 1.291 & & 1.071 & \\
\hline & $(2.26)$ & & $(1.99)$ & \\
\hline TOT & & 1.705 & & 1.737 \\
\hline & & $(2.09)$ & & $(2.13)$ \\
\hline long-term rate & & 0.149 & & 0.172 \\
\hline & & $(0.26)$ & & $(0.31)$ \\
\hline TFP & & -5.251 & & -5.284 \\
\hline & & $(8.60)$ & & $(8.65)$ \\
\hline money & & 0.055 & & 0.054 \\
\hline & & $(1.31)$ & & $(1.28)$ \\
\hline lab.dem. & & -2.582 & & -2.586 \\
\hline & & $(4.83)$ & & $(4.83)$ \\
\hline Observations & 175 & 175 & 175 & 175 \\
\hline Countries & 11 & 11 & 11 & 11 \\
\hline RMSE & 0.0316 & 0.0845 & 0.0318 & 0.0845 \\
\hline $\mathrm{R} 2$ & 0.9782 & 0.9787 & 0.9780 & 0.9788 \\
\hline
\end{tabular}

Notes: Both the wage inequality and the unemployment equations contain country and year dummies. See the notes of Table 2 for the explanatory variables in the wage inequality equation. The unemployment equation specification follows Nickell et al. (2004), and contains one lag of log unemployment. The shocks terms-of-trade (ToT), long-term real interest rate (long-term rate), total factor productivity (TFP), acceleration in money supply (money) and labor demand (lab. dem.) are defined in the data appendix. Absolute value of $z$ statistics in parentheses. 


\begin{tabular}{rccccr}
\hline \hline \multicolumn{5}{c}{ Percentage change of $\frac{w_{90}}{w_{10}}$ : } \\
\hline \hline & One standard-deviation reduction in rigidity \\
Baseline & 0.20 & BRR & BD & UD & MW \\
Interactions & 0.19 & 0.03 & 0.04 & 0.09 & 0.06 \\
& & 0.05 & 0.07 & 0.06
\end{tabular}

\begin{tabular}{|c|c|c|c|c|c|c|}
\hline & \multicolumn{6}{|c|}{ Change from most rigid to most flexible institutional regulation } \\
\hline & & EP & & & BRR & \\
\hline Baseline & & 0.59 & & & 0.09 & \\
\hline & $\times \mathbf{M W}_{\min }$ & $\times \mathbf{M W}_{\text {mean }}$ & $\times \mathbf{M W}_{\max }$ & $\times \mathbf{B D}_{\min }$ & $\times \mathbf{B D}_{\text {mean }}$ & $\times \mathbf{B D}_{\max }$ \\
\hline Interactions & 0.49 & 0.55 & 0.67 & 0.02 & 0.23 & 0.52 \\
\hline & & UD & & & MW & \\
\hline Baseline & & 0.25 & & & 0.16 & \\
\hline & $\times \mathbf{C O}_{\min }$ & $\times \mathbf{C O}_{\text {mean }}$ & $\times \mathbf{C O}_{\max }$ & $\times \mathbf{E P}_{\min }$ & $\times \mathbf{E P}_{\text {mean }}$ & $\times \mathbf{E P}_{\max }$ \\
\hline Interactions & 0.57 & 0.19 & -0.19 & 0.07 & 0.16 & 0.24 \\
\hline
\end{tabular}

\begin{tabular}{rcr}
\hline \hline & Time effects & \\
& $\mathbf{9 7 - 7 3}$ & $\mathbf{8 3 - 7 3}$ \\
Baseline & 0.22 & 0.17 \\
Interactions & 0.15 & 0.09 \\
& & \\
& & \\
\hline \hline
\end{tabular}

Notes: The simulations for the baseline model use the significant coefficients of the estimation in Table 3, column (1), and the model with interactions uses the coefficients in column (4), Table 4.

Table 7: Simulations of baseline model and with interactions I

\begin{tabular}{rrrrrrrrrrr}
\hline \hline \multicolumn{10}{c}{ Percentage change of $\frac{w_{90}}{w_{10}}$ if change in institutions to US levels } \\
\hline \hline Baseline & 0.33 & 0.19 & 0.52 & 0.50 & 0.50 & 0.52 & 0.40 & 0.61 & 0.67 & 0.14 \\
Interactions & 0.36 & 0.29 & 0.61 & 0.69 & 0.68 & 0.65 & 0.64 & 0.87 & 0.62 & 0.28 \\
\hline \hline
\end{tabular}

Notes: The countries are Australia (al), Canada (ca), Finland (fn), France (fr), Germany (ge), Italy (it), Japan (ja), the Netherlands (nl), Sweden (sw), United Kingdom (uk). The first row uses the significant coefficients of the estimation in Table 3, column (1), and the second row is based on Table 4, column (4).

Table 8: Simulations of baseline model and with interactions II 


\begin{tabular}{rrrrrrrrrrrrr}
\hline \hline \multicolumn{10}{c}{ Percentage change of } & $\frac{w_{90}}{w_{10}}$ associated with changes in institutions & $1973-1999$ \\
\hline \hline Baseline & -0.06 & -0.01 & -0.13 & -0.14 & 0.12 & 0.10 & -0.03 & 0.15 & -0.30 & 0.04 & 0.04 \\
Interactions & -0.08 & -0.02 & -0.15 & -0.20 & 0.08 & 0.19 & -0.10 & 0.11 & -0.32 & 0.13 & 0.08 \\
\hline \hline
\end{tabular}

Notes: The values for Australia refer to the period 1973-1985, for Germany 1991-1999. For Italy and the Netherlands the values from 1973-1985 are imputed. The countries are Australia (al), Canada (ca), Finland (fn), France (fr), Germany (ge), Italy (it), Japan (ja), the Netherlands (nl), Sweden (sw), United Kingdom (uk), United States (us). The first row uses the significant coefficients of the estimation in Table 3, column (1), and the second row is based on Table 4, column (4).

Table 9: Simulations of baseline model and with interactions III 


$\begin{array}{rrcc} & \mathbf{1 9 7 0 s} & \mathbf{1 9 8 0} \mathbf{s} & \mathbf{1 9 9 0 s} \\ \text { Australia } & 2.551 & 2.755 & \\ \text { Canada } & 3.224 & 3.771 & 3.878 \\ \text { Finland } & 2.530 & 2.545 & 2.463 \\ \text { France } & 3.467 & 3.385 & 3.368 \\ \text { Germany } & & & 2.562 \\ \text { Italy } & & 2.222 & 2.394 \\ \text { Japan } & 2.564 & 2.740 & 2.782 \\ \text { Netherlands } & & 2.324 & 2.605 \\ \text { Sweden } & 2.110 & 2.096 & 2.209 \\ \text { UK } & 2.566 & 2.949 & 3.344 \\ \text { US } & 3.488 & 4.049 & 4.627\end{array}$

$\begin{array}{rrrr} & \mathbf{1 9 7 0 s} & \mathbf{1 9 8 0 s} & \mathbf{1 9 9 0 s} \\ \text { Australia } & 0.013 & 0.013 & \\ \text { Canada } & 0.014 & 0.023 & 0.028 \\ \text { Finland } & 0.023 & 0.037 & 0.056 \\ \text { France } & 0.048 & 0.055 & 0.073 \\ \text { Germany } & & & 0.064 \\ \text { Italy } & & 0.038 & 0.037 \\ \text { Japan } & 0.013 & 0.027 & 0.044 \\ \text { Netherlands } & & 0.051 & 0.055 \\ \text { Sweden } & 0.069 & 0.093 & 0.107 \\ \text { UK } & 0.109 & 0.105 & 0.086 \\ \text { US } & 0.064 & 0.088 & 0.085\end{array}$

Unemployment rate

Import intensity

$\begin{array}{rrcc} & \mathbf{1 9 7 0 s} & \mathbf{1 9 8 0} \mathbf{s} & \mathbf{1 9 9 0 s} \\ \text { Australia } & 5.500 & 7.633 & \\ \text { Canada } & 5.500 & 8.233 & 10.300 \\ \text { Finland } & 5.800 & 4.667 & 12.325 \\ \text { France } & 4.880 & 9.020 & 11.100 \\ \text { Germany } & & & 6.071 \\ \text { Italy } & & 7.750 & 8.400 \\ \text { Japan } & 2.040 & 2.490 & 2.878 \\ \text { etherlands } & & 10.600 & 6.825 \\ \text { Sweden } & 1.550 & 2.130 & 6.283 \\ \text { UK } & 4.771 & 9.970 & 8.478 \\ \text { US } & 6.414 & 7.160 & 5.922\end{array}$

$\begin{array}{rrrr} & \mathbf{1 9 7 0 s} & \mathbf{1 9 8 0 s} & \mathbf{1 9 9 0 s} \\ \text { Australia } & 0.056 & 0.068 & \\ \text { Canada } & 0.080 & 0.110 & 0.132 \\ \text { Finland } & 0.075 & 0.083 & 0.088 \\ \text { France } & 0.049 & 0.070 & 0.091 \\ \text { Germany } & & & 0.074 \\ \text { Italy } & & 0.057 & 0.065 \\ \text { Japan } & 0.014 & 0.016 & 0.020 \\ \text { Netherlands } & & 0.210 & 0.205 \\ \text { Sweden } & 0.086 & 0.105 & 0.110 \\ \text { UK } & 0.064 & 0.086 & 0.103 \\ \text { US } & 0.022 & 0.035 & 0.049\end{array}$

Skill ratio

$\begin{array}{rrcr} & \mathbf{1 9 7 0 s} & \mathbf{1 9 8 0 s} & \mathbf{1 9 9 0 s} \\ \text { Australia } & 0.350 & 0.412 & \\ \text { Canada } & 0.361 & 0.675 & 0.836 \\ \text { Finland } & 0.157 & 0.218 & 0.293 \\ \text { France } & 0.174 & 0.233 & 0.315 \\ \text { Germany } & & & 0.253 \\ \text { Italy } & & 0.062 & 0.078 \\ \text { Japan } & 0.149 & 0.213 & 0.315 \\ \text { Netherlands } & & 0.152 & 0.227 \\ \text { Sweden } & 0.126 & 0.202 & 0.287 \\ \text { UK } & 0.100 & 0.133 & 0.184 \\ \text { US } & 0.379 & 0.546 & 0.867\end{array}$

Minimum wage indicator

$\begin{array}{rrrr} & \mathbf{1 9 7 0 s} & \mathbf{1 9 8 0 s} & \mathbf{1 9 9 0 s} \\ \text { Australia } & 0.000 & 0.108 & \\ \text { Canada } & 0.510 & 0.404 & 0.406 \\ \text { Finland } & 0.000 & 0.000 & 0.000 \\ \text { France } & 0.583 & 0.624 & 0.608 \\ \text { Germany } & & & 0.000 \\ \text { Italy } & & 0.000 & 0.000 \\ \text { Japan } & 0.289 & 0.307 & 0.300 \\ \text { Netherlands } & & 0.572 & 0.496 \\ \text { Sweden } & 0.000 & 0.000 & 0.000 \\ \text { UK } & 0.000 & 0.000 & 0.000 \\ \text { US } & 0.449 & 0.401 & 0.372\end{array}$

Table 10: Descriptive statistics for the data I 


$\begin{array}{rrrr} & \mathbf{1 9 7 0 s} & \mathbf{1 9 8 0 s} & \mathbf{1 9 9 0 s} \\ \text { Australia } & 0.500 & 0.500 & \\ \text { Canada } & 0.300 & 0.300 & 0.300 \\ \text { Finland } & 1.200 & 1.193 & 1.108 \\ \text { France } & 1.262 & 1.308 & 1.453 \\ \text { Germany } & & & 1.453 \\ \text { Italy } & & 1.985 & 1.804 \\ \text { Japan } & 1.400 & 1.400 & 1.400 \\ \text { Netherlands } & & 1.350 & 1.253 \\ \text { Sweden } & 1.560 & 1.782 & 1.470 \\ \text { UK } & 0.332 & 0.350 & 0.350 \\ \text { US } & 0.100 & 0.100 & 0.100\end{array}$

Benefit replacement ratio

$\begin{array}{rrcc} & \mathbf{1 9 7 0 s} & \mathbf{1 9 8 0 s} & \mathbf{1 9 9 0 s} \\ \text { Australia } & 0.235 & 0.225 & \\ \text { Canada } & 0.653 & 0.565 & 0.578 \\ \text { Finland } & 0.365 & 0.456 & 0.590 \\ \text { France } & 0.562 & 0.607 & 0.585 \\ \text { Germany } & & & 0.370 \\ \text { Italy } & & 0.037 & 0.263 \\ \text { Japan } & 0.300 & 0.286 & 0.309 \\ \text { Netherlands } & & 0.700 & 0.700 \\ \text { Sweden } & 0.644 & 0.767 & 0.796 \\ \text { UK } & 0.341 & 0.263 & 0.226 \\ \text { US } & 0.278 & 0.296 & 0.266\end{array}$

Benefit duration

$\begin{array}{rrcc} & \mathbf{1 9 7 0 s} & \mathbf{1 9 8 0 s} & \mathbf{1 9 9 0 s} \\ \text { Australia } & 1.020 & 1.021 & \\ \text { Canada } & 0.178 & 0.241 & 0.227 \\ \text { Finland } & 0.712 & 0.580 & 0.550 \\ \text { France } & 0.174 & 0.370 & 0.488 \\ \text { Germany } & & & 0.607 \\ \text { Italy } & & 0.000 & 0.142 \\ \text { Japan } & 0.000 & 0.000 & 0.000 \\ \text { Netherlands } & & 0.695 & 0.546 \\ \text { Sweden } & 0.049 & 0.050 & 0.045 \\ \text { UK } & 0.546 & 0.699 & 0.693 \\ \text { US } & 0.191 & 0.169 & 0.191\end{array}$

$\begin{array}{rrcc} & \mathbf{1 9 7 0 s} & \mathbf{1 9 8 0 s} & \mathbf{1 9 9 0 s} \\ \text { Australia } & 0.370 & 0.391 & \\ \text { Canada } & 0.426 & 0.442 & 0.503 \\ \text { Finland } & 0.578 & 0.607 & 0.634 \\ \text { France } & 0.605 & 0.650 & 0.672 \\ \text { Germany } & & & 0.524 \\ \text { Italy } & & 0.606 & 0.682 \\ \text { Japan } & 0.262 & 0.334 & 0.292 \\ \text { Netherlands } & & 0.541 & 0.439 \\ \text { Sweden } & 0.701 & 0.780 & 0.766 \\ \text { UK } & 0.455 & 0.506 & 0.459 \\ \text { US } & 0.424 & 0.440 & 0.453\end{array}$

Union coordination indicator

$\begin{array}{rrcr} & \mathbf{1 9 7 0 s} & \mathbf{1 9 8 0 s} & \mathbf{1 9 9 0 s} \\ \text { Australia } & 2.250 & 2.250 & \\ \text { Canada } & 1.000 & 1.000 & 1.000 \\ \text { Finland } & 2.250 & 2.250 & 2.250 \\ \text { France } & 1.750 & 1.863 & 2.000 \\ \text { Germany } & & & 3.000 \\ \text { Italy } & & 1.500 & 2.143 \\ \text { Japan } & 3.000 & 3.000 & 3.000 \\ \text { Netherlands } & & 2.000 & 2.000 \\ \text { Sweden } & 2.500 & 2.388 & 2.104 \\ \text { UK } & 1.500 & 1.388 & 1.069 \\ \text { US } & 1.000 & 1.000 & 1.000\end{array}$

Net union density

$\begin{array}{rrcc} & \mathbf{1 9 7 0 s} & \mathbf{1 9 8 0 s} & \mathbf{1 9 9 0 s} \\ \text { Australia } & 0.490 & 0.491 & \\ \text { Canada } & 0.325 & 0.366 & 0.365 \\ \text { Finland } & 0.664 & 0.707 & 0.779 \\ \text { France } & 0.210 & 0.147 & 0.101 \\ \text { Germany } & & & 0.291 \\ \text { Italy } & & 0.402 & 0.388 \\ \text { Japan } & 0.320 & 0.283 & 0.239 \\ \text { Netherlands } & & 0.272 & 0.244 \\ \text { Sweden } & 0.753 & 0.813 & 0.859 \\ \text { UK } & 0.546 & 0.509 & 0.381 \\ \text { US } & 0.250 & 0.191 & 0.152\end{array}$

Table 11: Descriptive statistics for the data II 